\title{
EQUITY LENDING MARKETS AND OWNERSHIP STRUCTURE
}

\author{
Pedro A.C. Saffi ${ }^{1}$ \\ Jason Sturges ${ }^{2}$
}

IESE Business School - University of Navarra

Av. Pearson, 21 - 08034 Barcelona, Spain. Phone: (+34) 932534200 Fax: (+34) 932534343

Camino del Cerro del Águila, 3 (Ctra. de Castilla, km 5,180) - 28023 Madrid, Spain. Phone: (+34) 913570809 Fax: (+34) 913572913

Copyright ${ }^{\odot} 2009$ IESE Business School.

\footnotetext{
${ }^{1}$ Professor of Financial Management, IESE

2 Professor, McDonough School of Business, Gerogetown University
} 


\title{
Equity Lending Markets and Ownership Structure *
}

\author{
Pedro A. C. Saffi ${ }^{\dagger} \quad$ Jason Sturgess $^{\ddagger}$ \\ This version: February 15th, 2010
}

\begin{abstract}
Using proprietary data on equity lending supply, loan fees and quantities we examine the link between institutional ownership structure and the market for equity lending and stock prices. We find that both total institutional ownership and ownership concentration - measured by the Herfindahl index, single largest holding, and number of investors - are important determinants of equity lending supply and short sale constraints. More concentrated ownership structures increase short sale constraints - including loan fees, recall risk and arbitrage risk - and forces arbitrageurs to decrease demand for equity borrowing and demand greater compensation for borrowing stock. The results suggest that the impact of institutional ownership structure in the equity lending market creates limits to arbitrage.
\end{abstract}

Keywords: Equity lending markets, short selling, ownership structure, lending supply, arbitrage risk.

JEL classification: G10, G11, G14, G18, G28, G32.

\footnotetext{
${ }^{*}$ We are immensely grateful to the equity lending data provided by Data Explorers. Thanks to seminar participants at Georgetown University, as well as Patrick Kelly. We also thank the Ministerio de Ciencia e Innovación de España for the research grant EC02008-05155/ECON. All errors are ours.

${ }^{\dagger}$ IESE Business School. Email: psaffi@iese.edu

${ }^{\ddagger}$ McDonough School of Business, Georgetown University. Email: jds224@georgetown.edu
} 


\section{Introduction}

An active market for lending and borrowing stock is important for efficient stock prices. Yet, an active market depends on active participants. Participants' demand for borrowing stock arises for hedging reasons or because an investor group concludes that stocks are overvalued. Supply for lending stock must arise from current owners choosing to lend their holdings in return for a fee. Why do stockholders participate in lending stock? One possible answer is that the longer investment horizon and lower portfolio turnover of institutional investors (like pension funds, insurance companies and index funds) make them choose to generate extra income by lending securities in exchange for a fee. However, there has been little to no empirical investigation into which institutional owners lend stock and, in turn, what impact this has on the market for equity lending.

In this paper we examine if ownership structure affects the market for lending and borrowing stock. We use a proprietary panel data set consisting of equity lending supply, loan prices and quantities from January 2005 to June 2008. Institutional ownership data is used to identify stocks with large individual investors or concentrated ownership and we present four main results.

First, we show that institutional ownership concentration negatively impacts stock lending supply, after controlling for total institutional ownership. Second, we examine the effect that ownership concentration has on the relationship between ownership levels and lending supply. We split our sample according to concentration quintiles and compare the impact of total ownership on lending supply between the smallest and largest quintiles of ownership concentration, finding that for high levels of concentration the impact of total ownership on lending supply is weakened. For firms with the most concentrated ownership structure, total ownership is insignificant in explaining lending supply.

Third, we switch attention to the economic costs of borrowing stock on measures of short sale constraints. We test whether the loan fee and loan fee volatility are higher for firms with 
high concentration and lower total ownership and if institutional ownership structure affects the likelihood of a stock becoming "special" in the lending supply market (i.e. it is costly to borrow). ${ }^{1}$ We also test if ownership structure affects loan recall risk through the type of lending contract (i.e. fixed-term or open-ended) and if arbitrage risk is higher for firms with higher concentration and smaller total ownership. Arbitrage risk measures the stock return volatility that is non-diversifiable and costly for arbitrageurs, being a proxy for limits of arbitrage [Wurgler and Zhuravskaya (2002)]. Overall, our findings are that total ownership relieves constraints, while ownership concentration increases the costs of borrowing equity and raises limits to arbitrage.

Fourth, we examine the demand for borrowing stock and its impact on stock returns. We hypothesize that arbitrageurs internalize the effects of ownership on lending supply and short sale constraints and, in turn, update their own demand curve. Specifically, for stocks with concentrated ownership, borrowing demand should decrease and returns should be higher to compensate arbitrageurs for the increased risk. We employ the methodology proposed by Cohen, Diether, and Malloy (2007) to identify demand shifts using price-quantity pairs. In logit regressions, we find that total ownership increases (decreases) and concentration decreases (increases) the likelihood of an outward (inward) demand shift. Furthermore, we find that where an outward demand shift occurs for a stock with concentrated ownership, abnormal returns are more negative to compensate arbitrageurs for higher limits to arbitrage and borrowing costs. These results suggest a link between the limits to arbitrage and ownership structure, which to the best of our knowledge has not been explored previously.

In robustness checks, we rule out several alternative hypotheses. We show that our results hold for alternate measures of concentration employing the largest institutional ownership holding, that do not rely on the number of institutional investors. We show that the results are robust to the use of a GMM estimator that corrects for the bias arising in fixed effect estimations of dynamic models.

\footnotetext{
${ }^{1}$ This term is due to the fact that these stocks are usually put on a "special" list that is closely followed by investors.
} 
Turning to the relationship between ownership structure and demand shifts, we re-examine the result that for stocks with concentrated ownership, borrowing demand decreases and returns are higher to compensate arbitrageurs for the increased risk. We rule out both the alternate hypothesis that the result is due to institutional investors and participants in the market for borrowing stock responding to news, and reverse causality.

As a taster of our main results, Figure 1 presents evidence that ownership structure affects equity lending markets and arbitrage risk. Sorting firms into twenty-five equal sized portfolios based on total institutional ownership and ownership concentration quintiles each quarter, we examine the cross-group differences in lending supply, loan fees, and arbitrage risk. Panel A of Figure 1 shows how equity lending supply is increasing in total ownership but decreasing in ownership concentration. Ownership concentration has a greater effect on supply where ownership is lower. Supply is, on average, greatest in the high-ownership low-concentration portfolio (26.9\%) and lowest in the low-ownership high-concentration portfolio (3.8\%). In Panel B, annualized loan fees are plotted against total ownership and concentration. Fees decrease in total ownership and increase in ownership concentration, and these results are amplified by concentration and total ownership respectively. The maximum average fee is $166 \mathrm{bps}$ in the low-ownership high-concentration portfolio, compared with a minimum average fee of $13.5 \mathrm{bps}$ in the high-ownership low-concentration portfolio. In Panel $\mathrm{C}$, we plot arbitrage risk. We find that arbitrage risk is significantly higher where both ownership is more concentrated and total ownership is lower. The figure illustrates that not only is ownership important, but that the interaction of total ownership and concentration has an impact of equity lending and limits to arbitrage.

As motivation for ownership structure impacting short sale constraints we refer to the Thomson Corp acquisition of Reuters. When Thomson Corp, the family-controlled Canadian data group, acquired Reuters in the summer of 2007, the new group became a dual-listed company, trading shares in London and Toronto. The Thomson family continued to own $55 \%$ of shares on the 
Toronto exchange. Following the conclusion of the deal in April 2008 the London listing has traded on average at a 15 per cent discount to the Toronto quote. The Financial Times reported "One factor was that the high concentration of the Thomson family's stake in Canada limited liquidity in Toronto, benefiting the price by restricting opportunities for borrowing stock to sell short", and that despite the twins arbitrage strategy of shorting Toronto-listed stocks and buying London-listed stocks, "6 per cent of the London line was on loan as of Friday, according to Data Explorers, compared to 5.4 per cent in Toronto". ${ }^{2}$

We are not the first to consider the benefits of actively constraining short sales. Lamont (2004) shows that overpricing increases when firms deliberately raise the level of short sale constraints. He describes one possible action "Firms can coordinate with shareholders to withdraw shares from the stock lending market, thus preventing short selling by causing loan recall.” The Thomson-Reuters example describes a specific example of this: a family firm, where the firm and shareholders restricting supply are the same decision maker. However, the extension to any shareholder choosing to constrain supply - whether acting alone or with firms - is obvious.

The paper is organized as follows. Section I places our work in the context of the existing literature on short sales and ownership structure. Section II describes data and outlines our main hypotheses between equity lending variables and ownership structure. Section IV presents results. Finally, Section V concludes.

\section{Literature Review}

Exploiting arbitrage opportunities often involves short sales of mispriced securities. The inability to locate securities to borrow can contribute to the persistence of price inefficiencies and prevent information revelation, making financial markets more inefficient and changing equilibrium asset

\footnotetext{
2“How parochialism hampered Thomson Reuters", Financial Times, June 24 2009, and "Concern over Thomson Reuters' UK listing”, Financial Times, January 92009.
} 
prices. There is a large body of academic research studying how short selling affects stock returns and market efficiency. Miller (1977) shows how short selling constraints lead to overvaluation due to the absence of pessimistic investors from the market. Diamond and Verrecchia (1987) propose a model in which short-sale constraints eliminate some informative trades. Prices are not biased upwards, but become less efficient when restrictions are in place, as they reduce the speed of adjustment to private information. Duffie, Garleanu, and Pedersen (2002) develop a model in which search costs and bargaining over loan fees generate endogenous short-sale constraints and affect asset prices.

Empirically, most studies use short interest (i.e the amount of common stock held in short positions) as proxy of short sales constraints, finding that stocks with high short interest exhibit lower subsequent returns [see for example Figlewski and Webb (1993); Desai, Ramesh, Thiagarajan, and Balachandran (2002); Jones and Lamont (2002); Asquith, Pathak, and Ritter (2004); Diether, Lee, and Werner (2005); Boehme, Danielsen, and Sorescu (2006); Boehmer, Jones, and Zhang (2008); and Akbas, Boehmer, Erturk, and Sorescu (2008)]

Measures of market efficiency like volatility, bid-ask spreads, skewness have also received attention. Reed (2007) studies rebate rates in the equity lending market as a proxy for short-sale constraints and shows that stock prices are slower to incorporate information when borrowing fees are high. Nagel (2005) uses institutional ownership as a proxy for short sale constraints and finds that constrained stocks exhibit lower returns and that both information flow and price efficiency are adversely affected by short sale constraints. Internationally, Bris, Goetzmann, and Zhu (2007) use regulatory information to conclude that stock prices in countries with constraints are less efficient than those where investors are allowed to short stocks. Saffi and Sigurdsson (2008) study the relationship between stock price efficiency and lending supply in international markets, finding that stocks with low lending supply or high loan fees are associated with smaller price efficiency.

The temporary ban on short selling imposed by the U.S. Securities and Exchange Commission 
in July and September 2008 spurred lots of research on the market impact of such regulatory restrictions. ${ }^{3}$ Bris (2008) finds that the July 15th, 2008 ban on naked short-selling (i.e. shorting shares before securing the borrowing of securities for delivery) of a subset of financial firms in the U.S. did not prevent negative performance and reduced intra-day volatility, but have increased bidask spreads and lowered market efficiency. Boehmer, Jones, and Zhang (2009) compare banned stocks to a control group and find that stocks subject to the temporary shorting ban in September 2008 suffered a severe reduction in spreads, price impacts, and intra-day volatility.

Most of these papers however, rely on indirect measures of short-sale constraints or a very restricted sample of lending data. For example, Kolasinski, Reed, and Ringgenberg (2008) use a database from twelve securities lenders to estimate the lending supply schedule and find that loan fees are relatively stable when demand is low, but highly variable when demand is high. Given that stock lending is mostly done over-the-counter, it has been unexplored by researchers because of poor data availability, especially information on the lending supply of shares. An exception is D'Avolio (2002), who describes in detail the market for borrowing and shows that institutional ownership can be used as a proxy for short-sales constraints, as they are more likely to bind among stocks with lower ownership by institutional investors. We are also close in spirit to Cohen, Diether, and Malloy (2007), who create a methodology to identify demand and supply shifts by observing price-quantity pairs and their impact of future stock returns. Our access to a comprehensive measure of lending supply allows us to directly test the impact of firm characteristics on lending supply. We advocate that this measure can be interpreted as a proxy for the cost of searching and, thus, as a measure of short-sale constraints.

\footnotetext{
${ }^{3}$ The SEC announcement can be found at: http://www.sec.gov/news/press/2008/2008-211.htm.
} 


\section{Research Design}

\section{A. Data}

We use a proprietary dataset of equity lending supply postings and loans from Data Explorers Ltd., which collects this information from a significant number of the largest custodians and prime brokers in the securities lending industry. ${ }^{4}$ The data comprise security-level information from January 2005 to June 2008, with weekly data between 2005 and 2006 and daily afterwards. As of June 2008 , there are $\$ 2.4$ trillion in stocks available to borrow, out of which $\$ 448$ billion are actually lent out. This corresponds to an utilization level (i.e., amount lent out divided by amount available to borrow) of around $17 \%$. Note that equity loans are not an explicit measure of short selling, since stock loans might be used as part of tax-arbitrage strategies [see for example Christoffersen, Geczy, and Musto (2006)].

The main dependent variables in our study are equity lending supply, loan amount, loan fee, and contract type. Equity supply postings contain the dollar value of shares available for borrowing on a given day (or week if before January 2007). We define lending supply as supply relative to a firm's market capitalization. Similarly, loan quantity is the dollar value of shares on loan on a given day relative to market capitalization. Loan fees are set in two different ways depending on the type of collateral placed by the borrower. If borrowers use cash - the dominant form in the U.S. - then the loan fee is defined as the difference between the risk-free interest rate and the rebate rate. The rebate rate is the portion of the interest rate on the collateral which the borrower receives back. If instead the transaction uses other securities as collateral, like U.S. Treasuries, the fee is directly negotiated between the borrower and the lender. The contract type variable examines whether equity loan transactions are open-term or fixed-term. Open-term loans are renegotiated

\footnotetext{
${ }^{4}$ The information is currently collected daily from 125 custodians and 32 prime brokers. Data Explorers estimate that the data represent $85 \%$ of global equity lending. See Saffi and Sigurdsson (2008) for a detailed description of the data.
} 
every day. Fixed-term ones have predefined clauses and maturities. The overnight risk-free rate of the collateral's currency is used for open-term loans. The Fed Open rate is used for loans with cash collateral denominated in U.S. dollars and the Euro Overnight Index average (EONIA) is used for loans denominated in Euros. The risk-free rate proxy for other currencies is the overnight rate at London Interbank market (LIBOR) and local money market rates for smaller currencies. Linear interpolation of LIBOR rates is used for fixed-term loans in accordance with conventions in the securities lending industry.

From these individual transactions, we compute daily averages for each firm in the sample. Since the ownership data is reported at a quarterly frequency, we then compute quarterly averages of equity lending variables for each firm, only including days with loan fees between -5\% and 20\% to reduce the impact of outliers. In some tests in which we use monthly abnormal returns, equity lending averages are computed at a monthly frequency.

In Figure 2 we plot the total lending supply and total loaned shares in billions of dollars (rightaxis) and the average utilization (left-axis) in a given quarter. We can observe the large increase in the equity lending market since 2005, both in terms of increased supply and loans. However, stock utilization levels have remained constant throughout the sample.

\section{[Insert Figure 2 HERE]}

In Figure 3 we show lending supply and loaned shares as a fraction of market capitalization (left-axis) and the average loan fee (right-axis). There is a large increase in database coverage in 2005, which shows the importance of working with normalized variables for each quarter to reduce biases due to calendar effects. Annualized fees have been relatively stable and show that, on average, it is very cheap to borrow shares in the U.S.. The average fee in June 2008 is around 0.6\% a year, similar to the figures reported by D'Avolio (2002) and Kolasinski, Reed, and Ringgenberg (2008). 
[Insert Figure 3 HERE]

The main explanatory variables in our study are measures of the structure of ownership held by institutional investors. The ownership data come from the Thomson Reuters CDA/Spectrum database on SEC 13F filings. Form $13 \mathrm{~F}$ is filed on a quarterly basis by institutional investment managers who exercise investment discretion over accounts holding at least \$100 Million in eligible equity securities. These managers report the total long positions in each eligible security, aggregated across all accounts over which they exercise investment discretion. ${ }^{5}$ The data is available until June 30th, 2008 for approximately 3,000 stocks. For each stock we calculate the ownership by each institution and total institutional ownership, both as a percentage of market capitalization. We also calculate our two main measures of ownership concentration: $H H I$ is the concentration of institutions' holdings using the Hirschman-Herfindahl Index, normalized to be between zero and one; and Breadth is the number of institutional investors from Chen, Hong, and Stein (2002).

We match firms in the equity lending database with those available on CRSP. The final sample has 34,367 firm-quarter observations with lending data available, averaging 10 quarterly observations out of the 3,598 unique firms. From CRSP data, we compute market capitalization, turnover and share price, cumulative quarterly returns, the standard deviation of daily returns, cumulative abnormal returns based on the Carhart (1997) four-factor model, and the market beta using the CRSP value-weighted market index as the benchmark. ${ }^{6}$ We only use common shares with prices larger than $\$ 1$, further merging the data to Compustat and collecting data on sales, total assets, book debt, book equity and total dividends.

\footnotetext{
${ }^{5}$ We thank Stewart Mayhew for detailed advice on 13F holdings.

${ }^{6}$ Betas and abnormal returns are estimated based on daily data with at least 60 days of observations for a given firm within a quarter.
} 


\section{B. Descriptive Statistics}

Table I presents descriptive statistics for the main variables used in this paper. The average firm in our sample has $17.67 \%$ of its market capitalization available to lend. On average, $4.81 \%$ of its capitalization is on loan, with the shares costing $0.43 \%$ per year to be borrowed. In our sample, $8.77 \%$ of firm-quarter observations are "on special", i.e. have lending fees above 100 basis points. Average total institutional ownership is above $70 \%$, with 176 institutions on average as shareholders of the typical firm.

\section{[Insert Table I HERE]}

Given our focus on lending supply, in Table II we report the sample's main characteristics sorted by lending supply quintiles. From Panel A, we find that the difference in lending supply between the lowest and highest quintiles is about $25 \%$ of market capitalization. The utilization of these shares (i.e. amount loaned out divided by lending supply) across quintiles is stable at around 20\%. As expected, loan fees are decreasing in supply, with firms with low supply being about five times more expensive to borrow (1.05\% per year) than those in the highest lending supply quintile ( $0.20 \%$ per year). These numbers are similar to those reported by D'Avolio (2002), albeit shares in our database are slightly more expensive and lent more often, which reflects the growth in the equity lending market in recent years and the fact that our data cover a much bigger number of data providers. We also find that firms with low supply tend to be smaller, have lower turnover and, perhaps surprisingly, low market betas.

Examining institutional ownership variables in Panel B, we find that total ownership grows with lending supply, consistent with their use as a proxy for lending supply as in Nagel (2005). We can also observe that the average size of institutional holdings decreases with lending supply, but holdings by the largest institutional shareholder are stable at around 10\%. Our two main measures of concentration, $H H I$ and Breadth also decrease and increase respectively with lending supply. In 
Panel C, we find that firms with higher supply tend to be larger, have higher stock turnover and analyst coverage, but lower arbitrage risk.

[Insert Table II HERE]

\section{Hypotheses}

We test four hypotheses on how the equity lending market is affected by the structure of institutional ownership. The hypotheses all build upon and develop the main idea that lending supply will be lower and short sale constraints more likely to bind when institutional ownership is concentrated among fewer investors.

Hypothesis 1 Lending supply is decreasing in the concentration of institutional ownership.

Recent literature has shown that short selling is associated with higher price efficiency and that it places downward pressure on stock prices [e.g. Asquith, Pathak, and Ritter (2004), Bris, Goetzmann, and Zhu (2007), Boehme, Danielsen, and Sorescu (2006), Cohen, Diether, and Malloy (2007) and Saffi and Sigurdsson (2008)]. Further, it has been argued that lending supply increases with institutional ownership and subsequently that it leads to an increase in price efficiency. The main idea behind these arguments is that large institutional owners are passive in nature and willing to lend stock that they hold [e.g. D’Avolio (2002) and Nagel (2005)].

On the contrary, where institutional ownership is more concentrated this may not necessarily hold true. A more concentrated ownership structure, or a structure including larger single institutional investors, results in shareholders having greater influence in the equity lending market vis-a-vis a highly dispersed ownership structure. Then, if shareholders prefer higher valuations, and short sale constraints allow stocks to be overpriced, shareholders should act to impede shortselling by limiting equity lending supply. Hypothesis 1 posits a negative relationship between ownership concentration and equity lending supply. 
In addition to the negative impact of concentration on lending supply predicted above, concentration should affect the strength of the relationship between lending supply and total institutional ownership. For low levels of ownership concentration, we expect a larger impact of total institutional ownership, as investors are less capable of influencing share prices with their holdings and therefore withhold relatively less shares. However, where concentration of ownership is high, institutional investors' supply is expected to have a greater influence on prices, and they are more likely to withhold their shares from the equity lending market. For example, the average ownership of the largest institutional shareholder in the lowest quintiles of total institutional ownership and ownership concentration (measured by the Hirschman-Herfindahl index) is $5.6 \%$, while for firms on the highest total institutional ownership and ownership concentration quintiles it is equal to $26.1 \%$.

Hypothesis 2 Short sale constraints are increasing in the concentration of institutional ownership.

While the effect of ownership structure on lending supply may be significant, there are economic consequences only if it affects the price of borrowing stock. Short selling carries various costs and risks, such as the expense and difficulty of shorting and the risk that the short position will have to be involuntarily closed due to recall of the borrowed shares. If these impediments prevent investors from shorting certain stocks, these stocks can be overpriced.

We examine the effects of institutional ownership structure on the following constraints. First, we examine the loan fee for borrowing stock. Second, we test if fee volatility is higher in stocks with more concentrated ownership. Higher fee volatility presents a higher risk to borrowing stock because borrowers are less certain about future borrowing costs. Third, we ask whether institutional ownership structure affects the likelihood of a stock becoming "special" in the lending supply market. Specialness is a commonly used term in lending markets that refers to stocks with large loan fees (defined here as loans with average annualized fees in a quarter above $100 \mathrm{bps}$ ). In 
our sample, about $10 \%$ of firms in a given quarter are classified as such. Fourth, we investigate if institutional ownership structure affects recall risk through the type of lending contract. Lending agreements can be open ended or fixed term. A fixed term contract specifies the term over which the stock is lent, while an open ended contract can be terminated at any point in time. The open ended contract involves much greater recall risk. Fifth, we examine if concentrated ownership increases arbitrage risk. We measure arbitrage risk by computing the standard deviation of the residuals based on the Carhart (1997) 4-factor model of returns. Firms with higher idiosyncratic volatility present riskier opportunities to arbitrageurs, measuring the volatility of returns that cannot be hedged [Wurgler and Zhuravskaya (2002)].

Hypothesis 3 Demand for borrowing stock is decreasing in the concentration of institutional ownership.

Hypotheses 1 and 2 describe the effects of ownership structure on equity lending supply and short sale constraints. At first blush it is not clear why the structure of institutional ownership should also be important for borrowing demand. If institutional owners make their holdings available to the equity lending market then this should only affect the supply of stock. Similarly, one assumes that demand originates from investors external to the firm who have no role to play in ownership structure. However, rational investors, and in particular potential arbitrageurs, will internalize the effects that influential institutional investors have on lending supply and short sale constraints. Consequently they will be less willing to borrow stock because of higher limits to arbitrage, and stocks with more concentrated ownership should have lower demand curves all else equal.

Unfortunately, we do not observe the demand curve for borrowing stock. Instead, we employ the methodology used in Cohen, Diether, and Malloy (2007) to focus on shifts in demand. If more concentrated ownership decreases the demand for borrowing stock, then the likelihood 
of an outward (inward) demand shift occurring should be decreasing (increasing) in ownership concentration.

Hypothesis 4 The returns associated with an outward demand shift are decreasing in the concentration of institutional ownership.

As documented in Cohen, Diether, and Malloy (2007) an outward demand shift results in future negative returns because more capital is betting that the price will decrease. Hypothesis 4 goes further and states that because concentrated ownership results in higher short sale constraints, the compensation must be greater for traders to increase their demand for borrowing when ownership is closely held. Compensation for borrowing the stock is through future negative returns, and therefore these need to be more negative where ownership is concentrated.

\section{Estimation Techniques}

Our main objectives are to evaluate the effects of ownership structure on equity lending characteristics and how these characteristics are related to limits of arbitrage and stock returns. Our universe of stocks comprises firms for which both Thomson Financial reports institutional ownership and Data Explorers collects equity lending data. Our baseline tests employ both estimation of quarterly regressions, reporting the average coefficients and their standard deviation (i.e. Fama-Macbeth), and also panel data regressions using fixed-effects to control for unobserved heterogeneity at the firm level and calendar-time dummies for heterogeneity over time. The regression takes the form:

$y_{i t}=\alpha_{i}+\theta_{t}+\beta_{1} I O_{i, t}+\beta_{2} I O C O N C_{i, t}+\beta_{2} M C_{i, t}+\beta_{4} D_{P<5, i, t}+\beta_{5} T O_{i, t}+\beta_{6} B M_{i, t}+\beta_{6} M O M_{i, t}+\epsilon_{i, t}$

where $y_{i t}$ is the equity lending measure, $I O_{i, t}$ denotes total institutional ownership, $I O C O N C_{i, t}$ is

institutional ownership concentration, $M C_{i, t}$ is market capitalization, $D_{P<5, i, t}$ is a dummy variable 
equal to one if stock price is less than five dollars, $T O_{i, t}$ is a stock turnover, $B M_{i, t}$ is book-tomarket, and $M O M_{i, t}$ is momentum.

These controls have been used by D'Avolio (2002) and control for relationships previously found in the literature. For example, firms with large market capitalization and turnover also tend to have a high lending supply of shares and be less expensive to borrow.

\section{Empirical Results}

\section{A. Lending Supply \& Institutional Ownership Structure}

The results in the left-most four columns of Table III indicate that lending supply is increasing in total ownership and decreasing in the concentration of institutional ownership. We include two measures of institutional ownership concentration. These are the Hirschman-Herfindahl index for institutional ownership, HHI; and the number of institutional investors, Breadth, from Chen, Hong, and Stein (2002). All specifications indicate that even after controlling for size, book-to-market, momentum, and small stock price effects, equity lending supply is increasing in total institutional ownership and decreasing in ownership concentration (or equivalently increasing in Breadth).

The coefficient of ownership concentration on equity lending supply is negative and statistically significant, and around a third the magnitude of the total ownership effect in the Fama-Macbeth specifications. For example, in the Fama-Macbeth regression we find that the coefficient on $H H I$ is -0.189 , while the coefficient on total ownership is 0.616 . Using normalized variables throughout, the coefficients imply that a one standard deviation increase in ownership concentration decreases lending supply by $2.1 \%$, and a one standard deviation increase in total ownership increases lending supply by 7.0\%. Similarly, equity lending supply is and increasing in Breadth. For Breadth, concentration is at least as important as total ownership: a one standard deviation increase in concentration combined with a one standard deviation increase in total ownership decreases equity 
lending supply.

[Insert Table III HERE]

Hypothesis 1 also posits that concentration will have an impact on the relationship between lending supply and total institutional holdings itself. For low levels of concentration, institutional investors' marginal impact on the lending market is likely smaller and they would have less incentives to withhold their shares from being lent. However, as concentration increases, investors are less likely to lend their shares. To capture this we introduce $\operatorname{Total}^{*} Q_{H H I}$ and Total ${ }^{*} Q_{\text {Breadth }}$, which are constructed by multiplying total ownership by the firm's ownership concentration $H H I$ and Breadth quintiles respectively. If concentration weakens the effect of total ownership on equity lending supply then the coefficient on $\operatorname{Total}^{*} Q_{H H I}$ (Total $* Q_{\text {Breadth }}$ should be negative (positive). The results in left-most four columns of Table III confirm this. Rows 1 to 3 show that the coefficients on total ownership, $H H I$ and $\operatorname{Total}^{*} Q_{H H I}$ are positive, negative, and negative respectively. Using estimates from the Fama-Macbeth regression in Column 6, for an otherwise equivalent firm, moving from the lowest to highest $H H I$ quintile reduces the effects of total ownership to 0.573 , a reduction of 0.324 , in addition to the coefficient of -0.208 on $H H I$ alone. The results are similar for Breadth, which are presented in Columns 7-8.

\section{B. Short Sale Constraints \& Institutional Ownership Structure}

As described in the hypothesis development, an important issue in analyzing the effects of ownership on equity lending is measuring to what extent ownership affects short sale constraints. While lending supply effects may be large, the importance may be moot if they do not have consequences for the pricing of borrowing stock, which in turn constrain short sales. We investigate the relationship between institutional ownership structure and short sale constraints by focusing on the cost of 
borrowing stock, loan fee volatility, the likelihood of a stock being on special, contract term, and arbitrage risk. All five characteristics may constrain short sales.

To explore the effects of ownership on short sale constraints we use the two measures of concentration in fixed effects and Fama-Macbeth regressions. First, in Table IV we examine loan fees and fee volatility. Panel A presents evidence that loan fees are higher where institutional ownership is more concentrated. If lower equity lending supply - as determined by ownership structure - has consequences for loan fees then we expect that total institutional ownership should have a negative or neutral affect on loan fees, and ownership concentration should decrease loan fees. For the most part we find this to be true. All specifications confirm a negative relationship between ownership concentration and lending fees, while both HHI and Breadth Fama-Macbeth specifications obtain a negative coefficient on total ownership. Focusing on the Fama-Macbeth regressions for $H H I$ shows that the effects of total ownership and ownership concentration are similar in size, while for Breadth the effects of concentration are larger. The coefficient on Total is -0.211 and for $H H I$ the coefficient is 0.171 , both statistically significant. These equate to a decrease of $21 \mathrm{bps}$ and an increase of $17 \mathrm{bps}$ in lending fee for a one standard deviation increase in total ownership and ownership respectively. Both compared to a mean lending fee of $49 \mathrm{bps}$. The evidence on loan fees supports Hypothesis 2: ownership concentration impedes short selling by increasing the cost of borrowing stock.

\section{[Insert Table IV HERE]}

Panel B examines loan fee volatility. Higher loan fee volatility creates a short sale constraint, or limit to arbitrage, because arbitrageurs may be exposed to a larger fee in the future where contract characteristics are not fixed. Loan fee volatility is calculated as the daily cross-sectional firm-level volatility in loan fee, averaged over each quarter. The mean (median) loan fee volatility is $29 \mathrm{bps}$ (12bps) with a standard deviation of 50bps, and is zero for a quarter of firm year observations. 
Generally, the loan fee is persistent, with an $\mathrm{AR}(1)$ coefficient of 0.8. The stocks with zero loan fee volatility indicates fee insensitivity to changes in demand, perhaps from low utilization or high slack supply. The results in Panel B offer further support for Hypothesis 2. All ownership concentration coefficients indicate that loan fees increase with ownership concentration. The economic impact on limits to arbitrage is large: a one standard deviation increase in $H H I$ (column two) is associated with an increase in volatility of +0.126 standard deviations in loan fee volatility, or approximately $5 \mathrm{bps}$.

In Table $\mathrm{V}$ we switch attention to the probability that a stock is "on special" or borrowed through a fixed term contract. Panel A of Table V presents results from a logit model where the dependent variable is equal to one if the stock is "on special" and zero otherwise. The left hand panel includes the logit specification coefficients while the right hand panel presents the marginal effects of a change around the man. For brevity only the variables of interest are presented. The results overwhelmingly support our hypothesis: the probability of a stock being "on special" increases with ownership concentration and decreases with total ownership. The marginal effects analysis reveals that a one standard deviation increase in $\mathrm{HHI}$ increases the probability of a stock being "on special" by $1.4 \%$, and total ownership decreases the probability by around $3.4 \%$, or approximately one-third of the sample average of $8.77 \%$. Similarly, the number of institutional investors has a negative and significant effect on the probability of a stock being on special.

In Panel B we examine the effects of ownership on contract type. A loan contract may be open-term, in which case the loan has a maturity of one day and is renewed each trading day, or for a fixed-term maturity. For open-term loans, the lender may recall the loan at the end of each day. The option to recall allows the lender to maintain the control rights of the share while receiving a borrowing fee. For a borrower, an open-ended contract significantly increases recall risk. Thus, if concentrated ownership increases limits to arbitrage through higher recall risk then we should expect the probability of fixed-term loans to be significantly lower where concentration is higher. 
We calculate loan-term at the firm-level as the equally weighted term across all loans for the firm on a given day, and then average this over the quarter of interest. A contract term of one day is taken to be an open-term contract. In our sample, approximately forty percent of all loan contracts are fixed-term contracts and the seventy-fifth percentile term is 1.64 days.

In Panel $\mathrm{B}$ of Table $\mathrm{V}$ we estimate logit regressions where the dependent variable is equal to one if the contract is fixed-term and zero if the contract is open-term. The results in Panel B support Hypothesis 2 but the magnitude of the marginal effects are smaller than for the results for a stock being "on special". A one standard deviation increase in total ownership increases the probability of the loan term being fixed by approximately $6.4 \%$, while a one standard deviation increase in concentration decreases the probability of the loan term being fixed by approximately $1.8 \%$.

\section{[Insert Table V HERE]}

In our final piece of analysis on short sale constraints we investigate the effect of ownership on arbitrage risk. Arbitrage risk is calculated using the Wurgler and Zhuravskaya (2002) idiosyncratic risk variable - measured as the standard deviation of stock returns' residuals estimated with the Carhart (1997) 4-factor model. For our sample, the average arbitrage risk is $2.11 \%$. Idiosyncratic risk poses a limit to arbitrage that deters short-selling simply because a large amount of the stocks' volatility cannot be hedged, as argued by Shleifer and Vishny (1997). Table VI presents the results from Fama-Macbeth regressions of arbitrage risk on ownership characteristics and control variables. We include equity lending supply and lending fee as independent variables in the regressions to control for any effects that short selling might have on idiosyncratic risk. In all regressions we find that higher equity lending supply is associated with less idiosyncratic risk. In addition, the effect of ownership structure on idiosyncratic risk is small but statistically significant. For example, in Column 1 a one standard deviation increase in total ownership decreases arbitrage risk by 5 bps and a one standard deviation decrease in $H H I$ increases arbitrage risk by 6bps (note 
that the standard deviation of arbitrage risk is equal to $1.22 \%$ ).

\section{[Insert Table VI HERE]}

In summary, limits to arbitrage are higher for stocks with more concentrated ownership structures. This result arises because tighter held ownership squeezes equity lending supply, which in turn increases the cost of borrowing stock - in both today's prices and the uncertainty in tomorrow's prices - and increases recall risk. Recall risk may be affected because where ownership is tighter or owners are more influential there is a much larger benefit from recalling stock around important proxy votes. Therefore non-marginal investors would be unwilling to lend equity on a fixed term basis. Lastly, we show that concentrated ownership is associated with an additional limit to arbitrage outside of the equity lending supply channel. Stocks with concentrated ownership exhibit higher arbitrage risk, which in the spirit of Shleifer and Vishny (1997) deters arbitrage and leads to persistent mis-pricing.

\section{The Demand for Borrowing Stock \& Institutional Ownership Structure}

We now turn attention to the demand for borrowing stock. Thus far we have shown that institutional ownership structure affects the level of equity lending supply provided by the same owners. However, as discussed in Section II.C, whenever investors and potential arbitrageurs anticipate institutional investor behavior on the supply side they should modify their own behavior. Specifically, arbitrageurs should internalize the higher short sale constraints and limits to arbitrage associated with more concentrated ownership into their demand function. Subsequently there may be lower demand for shorting stocks where institutional ownership is influential or more concentrated. Hypothesis 3 capture this. Demand for borrowing stock should be increasing in total ownership because this reduces short sale constraints - and decreasing in ownership concentration - because this increases short sale constraints. 
To investigate the effects of ownership structure on demand we employ the methodology proposed by Cohen, Diether, and Malloy (2007). The identification strategy consists of constructing price-quantity "pairs" from the equity lending market to isolate clear shifts in supply and demand. For example, an increase in the loan fee (i.e., price) coupled with an increase in the percentage of shares on loan (i.e., quantity) corresponds to an increase in shorting demand, as would be the case for any increase in price coupled with an increase in quantity. This strategy does not identify an exclusive outward demand shift. Instead, a shift of price and quantity into this quadrant implies that at least an outward demand shift must have occurred. We classify movements in loan prices and quantities by placing stocks into one of four quadrants at each point in time, but restrict attention to only demand shifts. Stocks that have experienced at least an outward demand shift (DOUT) have seen both their loan fees and their loan amounts rise; and stocks that experienced at least an inward demand shift $(D I N)$ have seen both their loan fee and loan quantity fall. Cohen, Diether, and Malloy (2007) also examine stocks that have experienced an outward supply shift (SOUT) and inward supply shift (SIN), but only find a minor role played by shifts in supply in determining stock returns.

Each of the shifts has an economic interpretation. DOUT captures the case in which both the cost of shorting (i.e., loan fee) and the amount that investors are willing to short at this higher cost increase. Effectively, more capital is betting that the price will decrease, despite the higher explicit cost of betting. DIN captures the case in which both shorting costs and the amount that investors borrow at this lower price decrease.

Using this strategy, we find that outward demand shifts comprise $39 \%$ of price-quantity "pairs" shifts, inward demand shifts contribute $15 \%$, outward supply shifts contribute $32 \%$, and inward supply shifts contribute $13 \%$. Combined, demand and supply shifts occur in $99 \%$ of firm-quarter observations. This is much greater than the aggregate shifts found by Cohen, Diether, and Malloy (2007), and likely due to the increased coverage in our dataset. Demand and supply shifts are likely 
to be correlated cross-sectionally because arbitrageurs' expectations of stock prices will reflect in part expectations of the market. To control for this, at each time period we first normalize shifts in the loan fee and quantity borrowed so that each has a mean of zero and standard deviation of one. We then use these to identify demand and supply shifts using normalized price-quantity "pairs" shifts. After normalization, $23 \%$ of price-quantity "pairs" are outward demand shifts, $36 \%$ are inward demand shifts, outward supply shifts comprise 22\%, and inward supply shifts $19 \%$.

To formally test Hypothesis 3 we estimate separate monthly logit regressions for normalized DOUT and DIN on lagged levels in ownership structure and market characteristics.

We compute demand shifts and market characteristics for each month, using monthly lags for lending supply and CRSP variables. However, we observe ownership variables at the quarterly frequency only and employ levels in the prior quarters as lagged explanatory variables.

The results are presented in Columns 1 and 2 of Table VII. For all shifts we run tests using all four concentration measures, but only show results for HHI. Focussing on DOUT, an outward demand shift is more likely if there is higher total ownership, or less concentrated ownership. The left hand panel presents the logit coefficients and the right hand panel presents the marginal coefficients. A one standard deviation increase in total ownership increases DOUT by $0.7 \%$ and a one standard deviation increase in ownership concentration decreases DOUT by $1.0 \%$. Focussing on DIN, we find the opposite: A one standard deviation increase in total ownership decreases DIN by $1.3 \%$ and a on standard deviation increase in ownership concentration increases DOUT by $0.8 \%$.

The results are consistent with short sale constraints impeding demand for borrowing stock. In isolation higher total ownership increases equity lending supply and lowers short sale constraints. Consider an arbitrageur deciding to execute a trade of shares in a firm with high dispersed institutional ownership. Potential arbitrageurs face lower fees and limits to arbitrage, which result in a higher proportion of potential trades being profitable and a higher demand to borrow equity. Sim- 
ilarly, consider a firm with very high concentrated ownership. Ownership concentration restricts equity lending supply and raises short sale constraints. The same arbitrageur will face higher fees and limits to arbitrage, a lower proportion of potential trades will be profitable, and the demand to borrow equity will be lower.

\section{[Insert Table VII HERE]}

An examination of the market characteristics reveals that inward demand shifts are more likely for large firms; higher turnover predicts inward demands shifts; outward demand shifts are more likely for growth (value) stocks; and that short-term momentum predicts outward demand shifts while long-term momentum predicts inward demand shifts.

In columns 3 and 4, we also present results for logit regressions of demand shifts on lagged dependent variables for the first month of each quarter only. Using the first month of the quarter only is motivated by the investment horizon of arbitrageurs and quarterly frequency of ownership variables. Similar to Cohen, Diether, and Malloy (2007), we find that the mean (median) holding period for borrowing stock is 38 (3) days, based on only fixed term borrowing contracts. Hence, including all monthly observations in Panel A involves regressing demand shifts on "stale" owner-

ship characteristics, which might bias results in favor of strengthening the significance of monthly frequency variables relative to quarterly-based ones. Regressions for the first month of the quarter only employs one-month lags throughout, reducing the sample size by a third. Examining the marginal effects in the right hand panel shows that using more recent observations leads to stronger results. For DOUT a one standard deviation increase in total ownership increases DOUT by $3.3 \%$ and a one standard deviation decreases in ownership concentration decreases DOUT by $1.2 \%$. Only the effect of $H H I$ on DIN is weaker.

An alternative to Hypothesis 3 is that ownership and demand shifts are related because institutional owners and arbitrageurs both receive information on future performance, and agree on the 
interpretation. Then, positive news results in both institutional ownership increasing and an inward demand shift. Similarly negative news should lead to a decrease in institutional ownership and an outward demand shift. Hence, DOUT (DIN) would be negatively (positively) associated with total ownership and likely positively (negatively) associated with ownership concentration. This prediction is robust to institutional investors and arbitrageurs forming beliefs on identical information or updating beliefs based on each other's actions. This alternative hypothesis based on investor sentiment has the exact opposite predictions to the limits to arbitrage based story we formulate in Hypothesis 3, being rejected by our findings.

\section{Demand shifts, Returns \& Institutional Ownership Structure}

Motivated by Cohen, Diether, and Malloy (2007), who show that DOUT shifts predict negative abnormal returns, Hypothesis 4 examines the returns where there is an outward demand shift and concentrated ownership. Hypothesis 4 is simply a result of the same mechanism described in Hypothesis 3. If concentrated supply increases limits to arbitrage then either demand for borrowing stock will decrease - because shorting stock is no longer profitable - or the gains to borrowing stock must be higher to compensate arbitrageurs. Cross-sectionally, we should observe that DOUT $(D I N)$ is lower (higher) and abnormal returns are higher for stocks with concentrated ownership. Similarly, we should observe that DOUT (DIN) is higher (lower) and abnormal returns are lower for stocks with higher total ownership.

We measure abnormal returns as the difference in the monthly stock return to those from a characteristics-matched benchmark portfolio sorted on market capitalization, book-to-market and momentum following Daniel, Grinblatt, Titman, and Wermers (1997). Then we estimate regressions using monthly abnormal returns, including calendar month dummies, and correct standard errors using robust standard errors clustered at the firm-level. We employ lagged ownership structure 
- relating to the level at the end of the previous quarter, lagged control variables, and contemporaneous demand shifts. The choice of lagged ownership characteristics and contemporaneous demand shifts is motivated by estimating the impact of observed ownership structure on arbitrageurs' demand decisions. Given, the short investment horizon of equity borrowers implies that return effects should be observed in days or weeks, rather than months. Consequently, using future monthly returns will overshoot the reaction window. Similarly, we include only the first month in each quarter to capture the most recent ownership observations. The dependent variables of interest are the interaction terms of total ownership and ownership concentration with demand shifts. We aggregate DIN and DOUT into a single DSHIFT variable, which is calculated as DOUT-DIN. DSHIFT is equal to one (minus one) if there is an outward (inward) demand shift and zero otherwise. We then interact DSHIFT with ownership structure quintiles.

We present the results in Table VIII. In Column 1 we replicate the result that demand shifts convey negative information for returns, documented by Cohen, Diether, and Malloy (2007). The coefficient on DSHIFT of -1.780 implies that a one standard deviation increase (decrease) in DSHIFT decreases (increases) abnormal returns by $1.78 \%$ per month (or an annualized $21.36 \%$ ). We interpret a shift from no shift to an outward or inward demand shift as being equivalent to a 1.36 standard deviations movement, based on the inverse of the standard deviation of DSHIFT equal to 0.734. Then, our findings suggest that an outward demand shift predicts an annualized abnormal return of $29 \%$.

\section{[Insert Table VIII HERE]}

In Column 2 we introduce $D S H I F T^{*} Q_{H H I}$, the interaction between demand shifts and ownership concentration, and the level in ownership concentration. We employ quintiles simply for ease of interpretation. Hypothesis 4 posits that for stocks with concentrated ownership there is a negative return in addition to the negative return associated with DSHIFT. Hence, Hypothesis 4 
predicts that the coefficient on $\operatorname{DSHIFT}^{*} Q_{H H I}$ should be negative and significant. We find precisely this. The coefficient of -0.187 on $D S H I F T * Q_{H H I}$ implies that, for an outward demand shift, the negative abnormal return from being in quintile five compared with quintile one in $H H I$ is equal to $8.98 \%$ per year $(=0.187 *(5-1) * 12)$, in addition to a negative annualized return of $15.04 \%$ for an outward demand shift alone.

We include interactions of demand shifts with both total ownership and ownership concentration in Column 3. We find that the negative return associated with an outward demand shift is significantly lower at $6.87 \%$ per year, with the remaining difference varying with total ownership and concentration. The coefficient of -0.161 on total ownership implies that for an outward demand shift, the additional negative abnormal return from being in quintile five compared with quintile one in total ownership is equal to $7.73 \%$ per year. Similarly, ownership concentration contributes an additional negative abnormal return of $12.4 \%$ per year.

Combined, the significance of the interaction terms reveal that total ownership enables outward demand shifts - and negative abnormal returns - through increasing available equity supply, and that ownership concentration increases negative abnormal returns for outward demand shifts as compensation for higher limits to arbitrage. Further, the results show that ownership structure effects explain almost three-quarters of the negative abnormal return predicted by demand shifts. In summary, Sections C and D support Hypotheses 3 and 4. The supply side constraints imposed by concentrated ownership structure impact demand decisions. Arbitrageurs face higher risks to arbitrage and decrease borrowing demand or demand higher returns in compensation. 


\section{Robustness}

\section{A. Alternative Measures of Ownership Structure}

Our two measures of ownership concentration, $H H I$ and Breadth, both analyze the concentration of institutional ownership using all owners. Both these measures will be smaller for larger more liquid stocks that have more diffuse ownership. While we control for both size and liquidity to be sure that our measure of concentration is not collecting these effects we check that our results our robust to two alternate measures of concentration. We introduce Topl and HS1, which measure he percentage held by the largest shareholder, and the ratio of the largest institutional holding to total institutional holdings. Both these measures examine concentration using the single largest owner and abstract from the number of institutional owners. ${ }^{7}$

Tables and X present robustness results using Topl and HS1 respectively. In both tables, Panel A repeats the Fama-Macbeth estimations for lending supply, lending fee, fee volatility, and arbitrage risk presented in Tables III, IV, and VI. Similarly, Panel B repeats the logit estimations for specialness and loan terms presented in Table V. For both Topl and HS1, we find overwhelming evidence in support of our earlier results.

\section{[Insert Table IX HERE]}

Additionally, where Topl and HS1 are high, the largest institutional investor is more likely to able to hold court with the firm's management. Then, Topl and HS1 may measure the level of influence that the largest institutional investor has on management, which in itself may determine whether an institutional owner is willing to lend shares. The decision to lobby or lend shares is similar to the decision to lobby or walk, which has been studied by Admati and Pfleiderer (2009), Edmans (2009) and Edmans and Manso (2009). Prior literature has used measures of investor

\footnotetext{
${ }^{7}$ In unreported results we also the top three- and five-largest institutional shareholders, with similar results.
} 
influence to show that firms with more influential institutional investors have higher CEO pay for performance and lower compensation [Hartzell and Starks, (2003)]. Our results suggest that concentrated and influential ownership structures both reduce equity lending.

[Insert Table X HERE]

\section{B. GMM Estimation}

Hankins and Flannery (2008) and Petersen (2009) show how empirical work in finance, which usually involves large number of firms (large $\mathrm{N}$ ) observed for small periods of time (small $\mathrm{T}$ ), needs to carefully address possible biases in estimation due to the correlation between unobserved heterogeneity and predetermined regressors. ${ }^{8}$

In our case, the high persistence of lending supply (first-order serial correlation is 0.96 and second-order is 0.90) might induce biases in ownership coefficients if we omit lagged supply as explanatory variables. We address this possibility with Blundell and Bond (1998)'s dynamic panel regressions.

The dynamic model we consider has $i=1, \ldots, N$ firms and $t=1, \ldots, T_{i}$ quarterly observations available for each firm, taking the form:

$$
y_{i t}=\sum_{j=1}^{p} \alpha_{j} y_{i, t-j}+x_{i, t} \beta+\nu_{i}+\epsilon_{i, t}
$$

where $x_{i, t}$ denotes our $k$ independent variables and time dummies, $\alpha_{1}, \ldots, \alpha_{p}, \beta$ is the vector of $p+k$ parameters to be estimated, $\nu_{i}$ are the firm-level fixed effects, and $\epsilon_{i, t}$ are i.i.d shocks.

The Blundell and Bond (1998) GMM estimator works by proposing a system of moment conditions in which lagged differences are used as instruments to the level equation and lagged levels

\footnotetext{
${ }^{8}$ There is a large body of research on panel-data estimation in the economics literature to address these biases, like Nickell (1981), Anderson and Hsiao (1982), Arellano and Bond (1991), Arellano and Bover (1995) and Blundell and Bond (1998).
} 
as instruments for the equation in differences. Since in panel models the removal of firm-level heterogeneity usually involves calculation of first differences, the transformed errors have a structure that is more complex than standard idiosyncratic shocks. In these equations, predetermined and endogenous variables in levels are instrumented with suitable lags of their own first differences. Our results find large differences in estimated parameters due to the omission of lags in dependent variables.

\section{[Insert Table XI HERE]}

Table reports estimates corresponding to the Blundell and Bond (1998) estimator. We repeat tests of ownership structure on lending supple, lending fee, and fee volatility for both $H H I$ and Breadth. Our results continue to obtain. Once again we find that lending supply increases with total ownership and decreases with ownership structure, while both the lending fee and fee volatility decrease with total ownership and increase with ownership structure.

\section{Causality of Ownership Structure and Demand Shifts}

Hypotheses 3 and 4 and the results in Tables and imply a causal link between ownership structure and demand shifts. In Table XII we confirm this and rule out reverse causality. We regress normalized ownership characteristics (that are explanatory variables in Table ) on lagged normalized demand shifts, normalized lending supply and stock characteristics using only observations. If ownership structure influences demand - rather than demand influences ownership structure - then demand and supply shifts should have no significance in determining future changes in ownership structure. In the main, the causal logit regression results show that ownership structure causally effects demand for borrowing stock. In Column 1 we can observe that neither lagged DOUT nor lagged DIN coefficients are statistically significant to explain total ownership. In Column 2, using 
$H H I$ as a measure of concentration, we find no relationship with lagged DOUT and a positive but weak (significant only at the $10 \%$ level) coefficient for lagged DIN.

[Insert Table XII HERE]

\section{Conclusion}

Arbitrageurs often use short selling as part of their trading strategies, borrowing securities they do not own to speculate on price decreases. Short selling entails various costs and risks, such as locating shares to borrow, loan fees, and the risk that the short position is involuntarily closed due to recall of the borrowed shares. We argue that investors who own large holdings or contribute to a more concentrated ownership structure are less willing to lend shares, affecting arbitrageurs' ability to engage in short selling.

The main objective of this paper is to examine how the composition of institutional ownership affects the market for borrowing stock. Using a proprietary data set with information on equity lending supply, loan transactions and loan fees we show that ownership structure is an important determinant of equity lending supply and short sale constraints. More specifically, we find that firms with low total ownership and high concentration of ownership tend to have smaller lending supply, higher loan fees, loan fees' volatility, and arbitrage risk. For example, firms in the lowownership high-concentration quintile have just 3.8\% of their market capitalization available to borrow, against $26.9 \%$ for firms in the high-ownership low-concentration quintile.

We use several measures of ownership concentration and statistical methods to show that institutional ownership concentration negatively impacts stock lending supply, after controlling for total institutional ownership. In addition, we examine the effect that ownership concentration has on the relationship between ownership levels and lending supply. We find that concentration weakens the impact of total ownership on lending supply, especially for those with high institutional owner- 
ship. For firms with the most concentrated ownership structure, total ownership is insignificant in explaining lending supply. We also examine measures of short sale constraints and find that total ownership relieves constraints while ownership concentration increases the costs of borrowing equity and raises limits to arbitrage.

Finally, we examine demand for borrowing stock and the impact of changes on stock returns. We hypothesize that arbitrageurs internalize the effects of ownership on lending supply and short sale constraints, updating their own demand curves. Arbitrageurs must be compensated for the higher risk associated with short selling stocks with concentrated ownership. We identify demand shifts using price-quantity pairs based on the methodology proposed by Cohen, Diether, and Malloy (2007) and find that total ownership increases (decreases) and concentration decreases (increases) the likelihood of an outward (inward) demand shift. When examining the impact of these shifts on stock returns we find that where an outward demand shift occurs, the stock returns are even more negative for firms with concentrated ownership, compensating arbitrageurs for the higher limits to arbitrage and borrowing costs. These results suggest a link between the limits to arbitrage and ownership structure, which to the best of our knowledge has not been explored previously.

During the financial crisis in 2008, regulators imposed short selling restrictions in several countries, especially following the bankruptcy of Lehman Brothers. ${ }^{9}$ Short selling regulation in the United States is currently under review by the Securities and Exchange Commission (SEC) and a better understanding of how equity lending markets are affected by the ownership structure is important for policy makers. ${ }^{10}$ The current opaqueness found in equity lending markets can and should be addressed by regulators and more disclosure on equity lenders of a given stock and the costs associated with borrowing shares would provide investors with a better understanding of the

\footnotetext{
${ }^{9}$ Please refer to http://www.dataexplorers.com/rsm for a comprehensive list of current short sale restrictions.

${ }^{10}$ For the latest information on the SEC's discussion: http://www.sec.gov/spotlight/shortsales.shtml
} 
risks involved in short selling.

In terms of future research, there are several directions that can be followed. For example, study how institutional ownership changes around mergers affect equity lending markets. The exchange of stock between shareholders with different characteristics, in terms of investment horizon, trading strategies and size of the stake, might trigger supply and demand shocks, affecting pricing in the lending market. The price effects associated with short selling could be another channel by which changes in corporate governance mechanisms affect stock prices. 


\section{References}

Admati, Anat R., and Paul C. Pfleiderer, 2009, The "Wall Street Walk" and Shareholder Activism: Exit as a Form of Voice, Review of Financial Studies, Forthcoming.

Akbas, Ferhat, Ekkehart Boehmer, Bilal Erturk, and Sorin M. Sorescu, 2008, Why Do Short Interest Levels Predict Stock Returns?, Working Paper.

Anderson, T. W., and Cheng Hsiao, 1982, Formulation and estimation of dynamic models using panel data, Journal of Econometrics 18, 47-82.

Arellano, Manuel, and Stephen Bond, 1991, Some Tests of Specification for Panel Data: Monte Carlo Evidence and an Application to Employment Equations, Review of Economic Studies 58, 277-97.

Arellano, Manuel, and Olympia Bover, 1995, Another look at the instrumental variable estimation of error-components models, Journal of Econometrics 68, 29-51.

Asquith, Paul, Parag A. Pathak, and Jay R. Ritter, 2004, Short Interest, Institutional Ownership and Stock Returns, Journal of Financial Economics 78, 243-276.

Blundell, Richard, and Stephen Bond, 1998, Initial conditions and moment restrictions in dynamic panel data models, Journal of Econometrics 87, 115-143.

Boehme, Rodney, Bartley R. Danielsen, and Sorin M. Sorescu, 2006, Short-sale constraints, dispersion of opinion and overvaluation, Journal of Financial and Quantitative Analysis.

Boehmer, Ekkehart, Charles M. Jones, and Xiaoyan Zhang, 2008, Which Shorts are Informed?, Journal of Finance 63, 491-527. 
Boehmer, Ekkehart, Charles M. Jones, and Xiaoyan Zhang, 2009, Shackling short sellers: The 2008 shorting ban, AFA 2010 Meetings Paper.

Bris, Arturo, 2008, Short Selling Activity in Financial Stocks and the SEC July 15th Emergency Order, IMD Working Paper.

Bris, Arturo, William N. Goetzmann, and Ning Zhu, 2007, Efficiency and the Bear: Short Sales and Markets Around the World, Journal of Finance 62, 1029-1079.

Carhart, Mark M., 1997, On Persistence in Mutual Fund Performance, The Journal of Finance 52, $57-82$.

Chen, Joseph, Harrison Hong, and Jeremy C. Stein, 2002, Breadth of ownership and stock returns, Journal of Financial Economics 66, 171-205.

Christoffersen, Susan E. Kerr, Christopher C. Geczy, and David K. Musto, 2006, Crossborder dividend taxation and the preference of taxable and non-taxable investors: Evidence from Canada, Journal of Financial Economics, Forthcoming.

Cohen, Lauren, Karl B. Diether, and Christopher J. Malloy, 2007, Supply and Demand Shifts in the Shorting Market, Journal of Finance 62, 2061-2096.

Daniel, Kent, Mark Grinblatt, Sheridan Titman, and Russ Wermers, 1997, Measuring Mutual Fund Performance with Characteristic-Based Benchmarks, Journal of Finance 52, 1035-58.

D’Avolio, Gene, 2002, The Market for Borrowing Stock, Journal of Financial Economics 66, $271-306$.

Desai, Hemang, K. Ramesh, S. Ramu Thiagarajan, and Bala V. Balachandran, 2002, An Investigation of the Informational Role of Short Interest in the Nasdaq Market, Journal of Finance 57, $2263-2287$. 
Diamond, Douglas W., and Robert E. Verrecchia, 1987, Constraints on short-selling and asset price adjustment to private information, Journal of Financial Economics 18, 277-311.

Diether, Karl B., Kuan-Hui Lee, and Ingrid M. Werner, 2005, Can Short-sellers Predict Returns? Daily Evidence, Working Paper Ohio State University.

Duffie, Darrel, Nicolae Garleanu, and Lasse Heje Pedersen, 2002, Securities lending, shorting, and pricing, Journal of Financial Economics 66, 307-339.

Edmans, Alex, 2009, Blockholder Trading, Market Efficiency, and Managerial Myopia, Journal of Finance, Forthcoming.

Edmans, Alex, and Gustavo Manso, 2009, Governance Through Exit and Voice: A Theory of Multiple Blockholders, AFA 2009 San Francisco Meetings Paper.

Figlewski, Stephen, and Gwendolyn P. Webb, 1993, Options, Short Sales, and Market Completeness, Journal of Finance 48, 761-777.

Hankins, Kristine Watson, and Mark J. Flannery, 2008, Estimating Dynamic Panel Models in Corporate Finance, Working Paper.

Hartzell, Jay C., and Laura T. Starks, 2003, Institutional Investors and Executive Compensation, Journal of Finance 58, 2351-2374.

Jones, Charles M., and Owen A. Lamont, 2002, Short-sale constraints and stock returns, Journal of Financial Economics 66, 207 - 239.

Kolasinski, Adam C., Adam V. Reed, and Matthew C. Ringgenberg, 2008, A Multiple Lender Approach to Understanding Supply and Demand in the Equity Lending Market, Working Paper. 
Lamont, Owen, 2004, Go Down Fighting: Short Sellers vs. Firms, NBER Working Paper No. 10659.

Miller, Edward M., 1977, Risk, Uncertainty, and Divergence of Opinion, Journal of Finance 32, $1151-68$.

Nagel, Stefan, 2005, Short sales, institutional investors and the cross-section of stock returns, Journal of Financial Economics 78, 277-309.

Nickell, Stephen J., 1981, Biases in Dynamic Models with Fixed Effects, Econometrica 49, 141726.

Petersen, Mitchell A., 2009, Estimating Standard Errors in Finance Panel Data Sets: Comparing Approaches, Review of Financial Studies 22, 435-480.

Reed, Adam V., 2007, Costly Short-Selling and Stock Price Adjustment to Earnings Announcements, Working Paper University of North-Carolina at Chapel Hill.

Saffi, Pedro A. C., and Kari Sigurdsson, 2008, Price Efficiency and Short-selling, IESE Business School Working Paper No. 748.

Shleifer, Andrei, and Robert W. Vishny, 1997, The Limits of Arbitrage, Journal of Finance 52, $35-55$.

Wurgler, Jeffrey, and Ekaterina Zhuravskaya, 2002, Does Arbitrage Flatten Demand Curves for Stocks?, Journal of Business 75, 583-608. 
Figure 1. Lending Supply, Loan Fees and Arbitrage Risk: Total Ownership vs. Concentration Quintiles

The figure displays quarterly lending supply, loan fees and arbitrage risk of U.S. firms from January 2005 to June 2008 sorted on total institutional ownership quintiles and then, within each quintile, further sorted on ownership concentration quintiles. Concentration is measured by the HirschmanHerfindahl index of institutional ownership. Lending Supply is the quarterly average fraction of the firm available to lend, Loan Fee is the value-weighted average equity loan fee (\% p.a.), and Arbitrage Risk is the idiosyncratic risk of daily returns from a regression based on the Carhart 4-factor model.
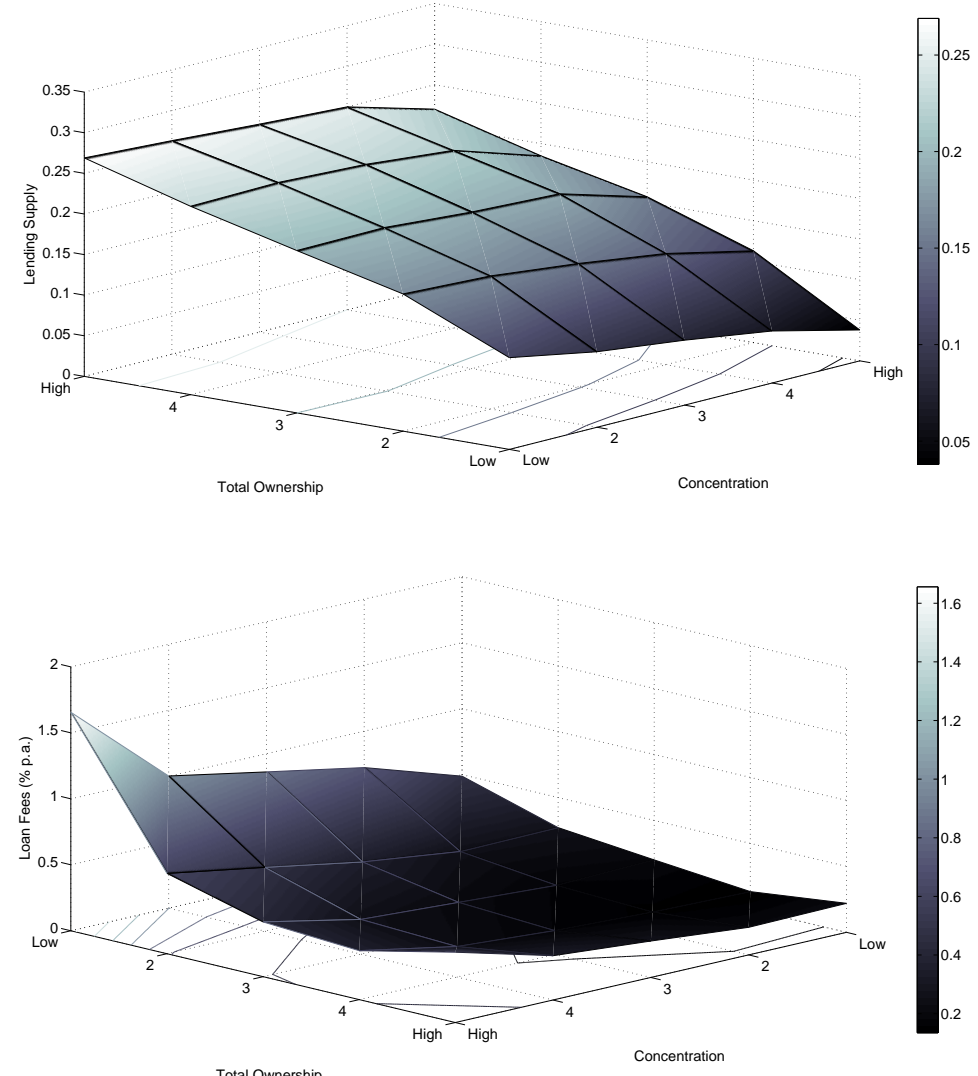

Total Ownership

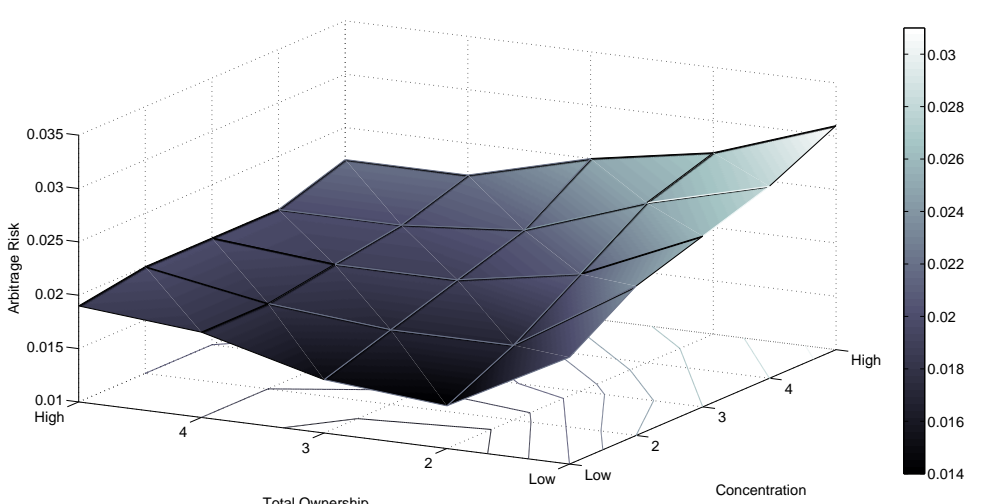


Figure 2. Equity Lending Market - Total Size and Utilization

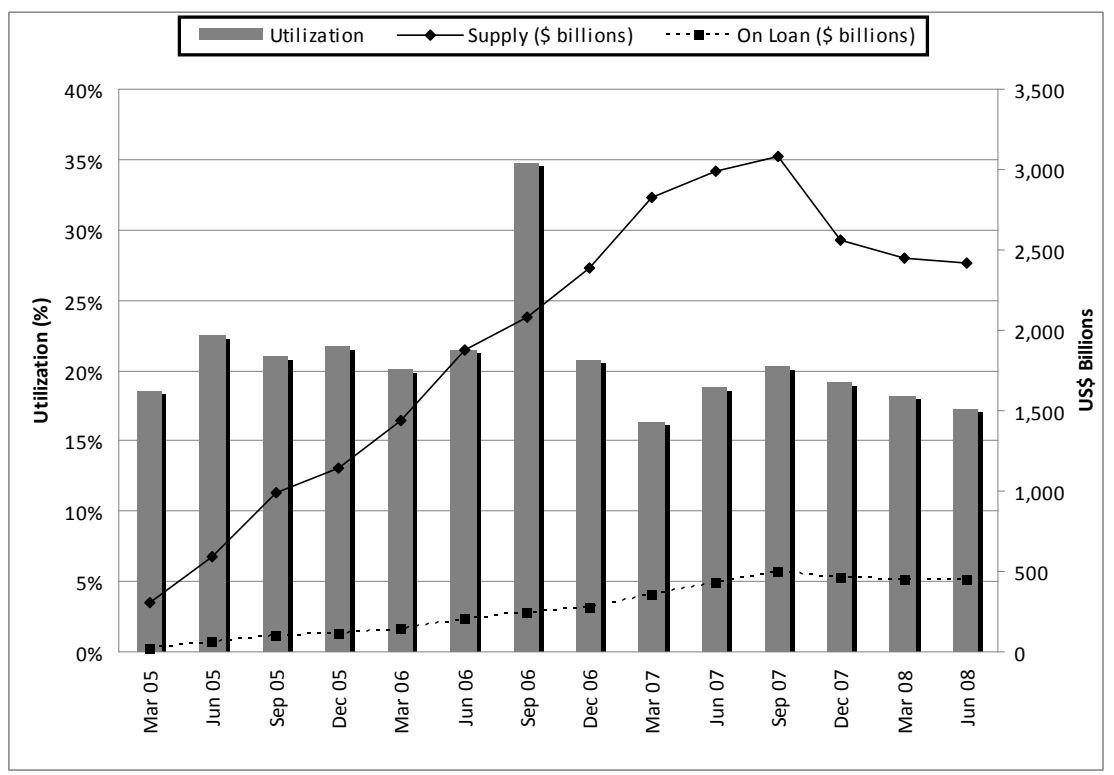

The figure shows the total lending supply, total shares on loan and the average utilization (shares on loan divided by lending supply) for each quarter between March 2005 and June 2008.

Figure 3. Equity Lending Market - Size relative to Capitalization and Loan Fees

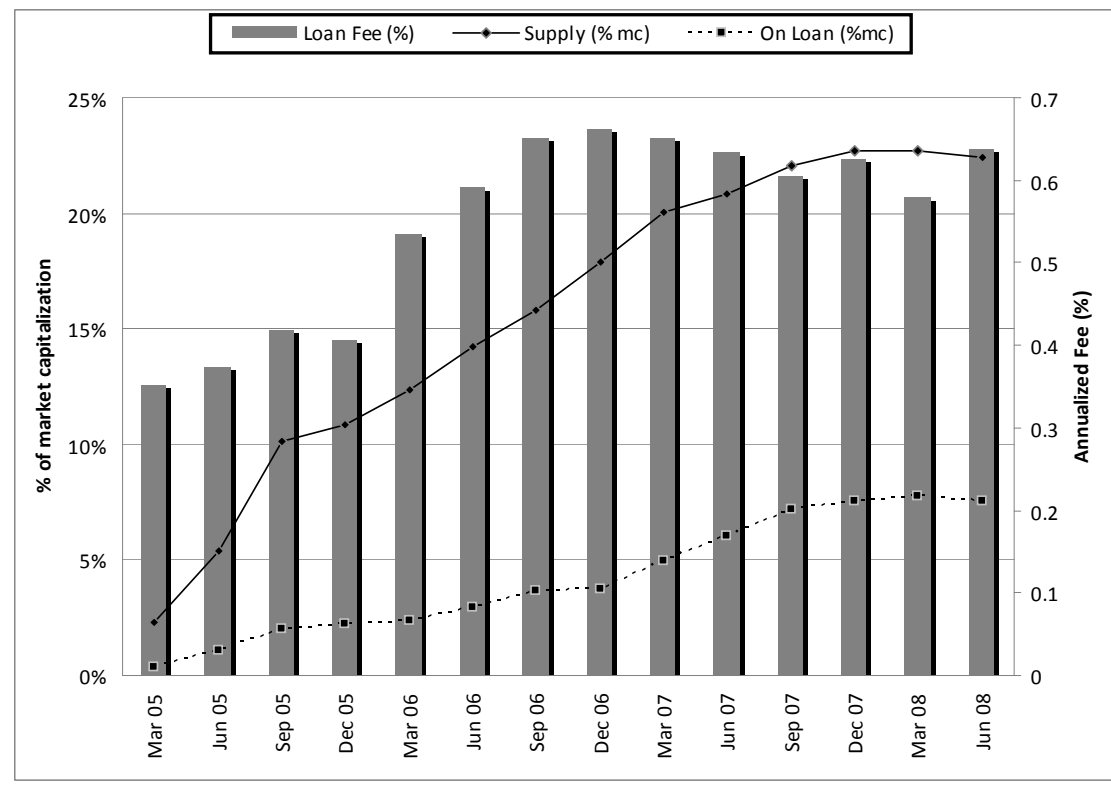

The figure shows average lending supply and the average shares on loan as a fraction of firm capitalization, and average value-weighted annualized loan fee for each quarter between March 2005 and June 2008. 


\section{Table I}

\section{Descriptive Statics}

The table shows quarterly descriptive statistics from January 2005 to June 2008 of the main variables used in the paper. Equity lending data is provided by Data Explorers, stock price are from CRSP, ownership data from SEC's 13F holdings, and accounting data from Compustat. Obs is the number of firm-quarter observations available, Supply is the quarterly average fraction of the firm available to lend, On Loan is the average fraction effectively lent out, Fee(VW) is the value-weighted average loan fee, Specialness is a dummy variable equal to one if the loan fee is above 100bps (summary statistics describe sample metrics), Util. is On Loan divided by Supply, Price is the quarterly CRSP price average, Size is firm size in billions, $\mu($ Ret $)$ is the average monthly return, $\sigma($ Ret $)$ is the standard deviation of returns, Turnover is average daily turnover (x100), Arb. Risk is the idiosyncratic risk of daily returns from a regression based on the Carhart (1997) 4-factor model, $\beta_{m k t}$ is the market beta from the same regression, and B/M is the book-to-market ratio. Ownership statistics are computed from institutional investors filling 13-f reports. Total is the total institutional ownership, HHI is concentration of ownership measured by the Hirschman-Herfindahl index, Mean is the average size of holdings, Top1 is the percentage held by the largest shareholder, HS1 measures investors' influence as in Hartzell and Starks (2003). Breadth is the number of institutional investors as in Chen, Hong, and Stein (2002). Net Sales and Total Assets are measured in millions and Leverage is book debt divided by the sum of book debt and market capitalization.

\begin{tabular}{lcccccc}
\hline Variable & Obs & Mean & Median & St.Dev & Min & Max \\
\hline Supply & 34,367 & $17.67 \%$ & $16.64 \%$ & $11.30 \%$ & $0.46 \%$ & $46.47 \%$ \\
On Loan & 34,366 & $4.81 \%$ & $2.44 \%$ & $5.91 \%$ & $0.01 \%$ & $28.41 \%$ \\
Fee (VW) & 34,367 & $0.43 \%$ & $0.13 \%$ & $0.99 \%$ & $-0.01 \%$ & $6.44 \%$ \\
Specialness & 34,367 & $8.77 \%$ & $0.00 \%$ & $28.29 \%$ & $0.00 \%$ & $100 \%$ \\
Utilization & 34,367 & $20.57 \%$ & $14.00 \%$ & $19.57 \%$ & $0.20 \%$ & $82.91 \%$ \\
Price & 34,367 & 63.05 & 23.79 & 1,919 & 0.31 & 135,459 \\
Size (bi) & 34,367 & 6.96 & 6.81 & 1.64 & 1.73 & 12.65 \\
$\mu($ Ret) & 34,367 & $0.66 \%$ & $0.20 \%$ & $20.97 \%$ & $-88.07 \%$ & $338 \%$ \\
$\sigma($ Ret) & 34,367 & $19.32 \%$ & $17.56 \%$ & $9.96 \%$ & $1.13 \%$ & $314 \%$ \\
Arb. Risk & 34,367 & $2.11 \%$ & $1.86 \%$ & $1.22 \%$ & $0.14 \%$ & $38.49 \%$ \\
Turnover & 34,367 & $1.02 \%$ & $0.79 \%$ & $0.93 \%$ & $0.01 \%$ & $31.09 \%$ \\
$\beta_{m k t}$ & 34,367 & 1.00 & 1.00 & 0.65 & -0.87 & 2.76 \\
B/M & 34,353 & 0.48 & 0.42 & 0.32 & 0.01 & 1.79 \\
Total & 34,367 & $70.28 \%$ & $74.87 \%$ & $23.58 \%$ & $0.00 \%$ & $100 \%$ \\
HHI & 34,367 & $7.00 \%$ & $5.09 \%$ & $6.45 \%$ & $1.33 \%$ & $100 \%$ \\
Mean & 34,367 & $0.68 \%$ & $0.60 \%$ & $0.46 \%$ & $0.00 \%$ & $8.96 \%$ \\
Stdev & 34,367 & $1.48 \%$ & $1.34 \%$ & $0.86 \%$ & $0.00 \%$ & $17.92 \%$ \\
Top1 & 34,367 & $10.20 \%$ & $9.37 \%$ & $5.58 \%$ & $0.00 \%$ & $100 \%$ \\
HS1 & 34,367 & $15.89 \%$ & $13.48 \%$ & $9.36 \%$ & $3.57 \%$ & $100 \%$ \\
Breadth & 34,367 & 176 & 124 & 179 & 1 & 1,603 \\
Sales & 34,328 & 949 & 168 & 2,988 & $-4,790$ & 80,962 \\
Assets & 34,367 & 10,264 & 993 & 72,921 & 1 & $2,358,266$ \\
Leverage & 32,810 & $30.61 \%$ & $27.94 \%$ & $26.33 \%$ & $0.00 \%$ & $96.21 \%$ \\
\hline
\end{tabular}




\section{Table II}

\section{Descriptive Statics - Lending Supply Quintiles}

The table shows quarterly descriptive statistics of U.S. firms from January 2005 to June 2008 sorted by equity lending supply quintiles. Equity lending data are supplied by Data Explorers Ltd., price data by CRSP, ownership data from SEC's $13 F$ holdings, analyst data from IBES, and accounting information by Compustat. Panel A displays equity lending market statistics: Obs supply is the number of firm-quarter observations for which lending supply data is available, Supply is the quarterly average fraction of market capitalization available to lend, On Loan is the average fraction effectively lent out, Specialness is a dummy variable equal to one if the loan fee is above 100bps, Util. is On Loan divided by Supply and Fee(VW) is the value-weighted average loan fee. Panel B reports institutional ownership characteristics. Total is total institutional ownership, Mean is the average size of holdings, StDev is the standard deviation, Top1 and Top3 are the percentages held by the largest and the three-largest shareholders, $\mathrm{HHI}$ is concentration of ownership measured by the Hirschman-Herfindahl index, HS1 measures investors' influence as in Hartzell and Starks (2003) and Breadth is the number of institutional investors as in Chen, Hong, and Stein (2002). Panel $\mathrm{C}$ reports summary statistics from Compustat and IBES: Price is the quarterly CRSP price average, Size is firm size in billions, $\mu$ (Ret) is the average monthly return, $\sigma($ Ret $)$ is the standard deviation of returns, Arb. Risk is the idiosyncratic risk of daily returns based on the Carhart (1997) 4-factor model, $\beta_{m k t}$ is the market index beta from the Carhart (1997) 4 factor model, Assets is total assets, Lever. is the book debt divided by the sum of book debt and market capitalization, and Analysts reports analyst coverage.

Panel A: Equity Lending

\begin{tabular}{ccccccc}
\hline Quintile & Obs Supply & Supply & On Loan & Specialness & Util. & Fee(VW) \\
\hline 1 & 6,879 & $5.9 \%$ & $2.1 \%$ & $27.2 \%$ & $25.1 \%$ & $1.05 \%$ \\
2 & 6,873 & $13.3 \%$ & $4.1 \%$ & $8.0 \%$ & $21.9 \%$ & $0.40 \%$ \\
3 & 6,874 & $18.0 \%$ & $4.4 \%$ & $3.6 \%$ & $17.8 \%$ & $0.25 \%$ \\
4 & 6,873 & $22.2 \%$ & $5.4 \%$ & $2.9 \%$ & $17.7 \%$ & $0.22 \%$ \\
5 & 6,868 & $29.0 \%$ & $8.0 \%$ & $2.2 \%$ & $20.3 \%$ & $0.20 \%$ \\
\hline Overall & 34,367 & $17.7 \%$ & $4.8 \%$ & $8.8 \%$ & $20.6 \%$ & $0.43 \%$ \\
\hline
\end{tabular}

Panel B: Institutional Ownership

\begin{tabular}{ccccccccc}
\hline Quintile & Total & Mean & StDev & Top1 & Top3 & HHI & HS1 & Breadth \\
\hline 1 & $40.9 \%$ & $1.0 \%$ & $1.9 \%$ & $10.1 \%$ & $19.5 \%$ & $13.9 \%$ & $25.8 \%$ & 60 \\
2 & $62.5 \%$ & $0.7 \%$ & $1.5 \%$ & $10.0 \%$ & $21.2 \%$ & $6.9 \%$ & $16.2 \%$ & 159 \\
3 & $74.5 \%$ & $0.5 \%$ & $1.3 \%$ & $9.9 \%$ & $21.6 \%$ & $5.2 \%$ & $13.3 \%$ & 253 \\
4 & $82.9 \%$ & $0.6 \%$ & $1.3 \%$ & $10.2 \%$ & $23.0 \%$ & $4.6 \%$ & $12.4 \%$ & 229 \\
5 & $90.6 \%$ & $0.7 \%$ & $1.5 \%$ & $10.8 \%$ & $24.7 \%$ & $4.4 \%$ & $11.7 \%$ & 181 \\
\hline Overall & $70.3 \%$ & $0.7 \%$ & $1.5 \%$ & $10.2 \%$ & $22.0 \%$ & $7.0 \%$ & $15.9 \%$ & 176 \\
\hline
\end{tabular}

Panel C: Pricing, Accounting and Analyst Coverage Data

\begin{tabular}{ccccccccccc}
\hline Quintile & Price & Size(bi) & $\mu($ Ret $)$ & $\sigma($ Ret $)$ & Arb. Risk & Turnover & $\beta_{m k t}$ & Assets & Lever. & Analysts \\
\hline 1 & 185.74 & 5.57 & $0.6 \%$ & $2.9 \%$ & $2.73 \%$ & $0.63 \%$ & 0.75 & 1,980 & 0.30 & 3.16 \\
2 & 26.68 & 6.84 & $0.6 \%$ & $2.5 \%$ & $2.13 \%$ & $0.90 \%$ & 1.00 & 7,864 & 0.32 & 5.50 \\
3 & 34.11 & 7.63 & $0.9 \%$ & $2.2 \%$ & $1.85 \%$ & $1.03 \%$ & 1.04 & 23,472 & 0.33 & 7.32 \\
4 & 35.01 & 7.60 & $1.6 \%$ & $2.2 \%$ & $1.87 \%$ & $1.19 \%$ & 1.09 & 12,849 & 0.31 & 7.78 \\
5 & 33.60 & 7.19 & $-0.4 \%$ & $2.3 \%$ & $1.97 \%$ & $1.35 \%$ & 1.11 & 5,155 & 0.28 & 6.90 \\
\hline Overall & 63.05 & 6.96 & $0.7 \%$ & $2.4 \%$ & $2.11 \%$ & $1.02 \%$ & 1.00 & 10,264 & 0.31 & 6.13 \\
\hline
\end{tabular}




\section{Table III: Lending Supply \& Corporate Ownership Structure}

The table displays regressions of equity lending supply as a function of corporate ownership measures, with quarterly stock data from January 2005 to June 2008 of U.S. firms. Each column corresponds to a different estimator, showing results for fixed-effects and Fama-Macbeth regressions. All variables are standardized each quarter such that they have zero mean and unit standard deviation. Total is total ownership, HHI is concentration of ownership measured by the Hirschman-Herfindahl index, Breadth is the number of institutional investors as in Chen, Hong, and Stein (2002), Mkt. Cap. denotes market capitalization, $D_{P<5}$ is a dummy variable equal to one if the quarterly average price is below five dollars, Turnover measures the quarterly average of daily stock turnover, B/M the book-to-market ratio, and Momentum is the cumulative return in the previous two quarters. Q $(z)$ represents the quintile sorted according to variable $z$. All regressions include year-quarter dummies, and fixed-effects' standard deviations are clustered at the firm level. We report standard deviations in brackets and significance levels are indicated as follows: $+=$ statistical significance at the $1 \%$ level, $* *=$ significant at the $5 \%$ percent level, *=significant at the $10 \%$ level.

\begin{tabular}{|c|c|c|c|c|c|c|c|c|}
\hline Variable & $\mathrm{FE}$ & F-M & FE & F-M & $\mathrm{FE}$ & F-M & $\mathrm{FE}$ & F-M \\
\hline \multirow[t]{2}{*}{ Total } & $0.464^{+}$ & $0.616^{+}$ & $0.425^{+}$ & $0.542^{+}$ & $0.643^{+}$ & $0.897^{+}$ & $0.238^{+}$ & $0.340^{+}$ \\
\hline & [0.018] & {$[0.023]$} & {$[0.019]$} & {$[0.020]$} & {$[0.030]$} & {$[0.044]$} & [0.027] & {$[0.036]$} \\
\hline \multirow[t]{2}{*}{ HHI } & $-0.028^{*}$ & $-0.189^{+}$ & & & $-0.040^{+}$ & $-0.208^{+}$ & & \\
\hline & {$[0.015]$} & [0.013] & & & {$[0.014]$} & {$[0.014]$} & & \\
\hline \multirow[t]{2}{*}{ Total $^{*} \mathrm{Q}_{H H I}$} & & & & & $-0.052^{+}$ & $-0.081^{+}$ & & \\
\hline & & & & & [0.007] & [0.008] & & \\
\hline \multirow[t]{2}{*}{ Breadth } & & & $0.256^{+}$ & $0.656^{+}$ & & & $0.319^{+}$ & $0.764^{+}$ \\
\hline & & & {$[0.051]$} & {$[0.052]$} & & & {$[0.052]$} & [0.049] \\
\hline \multirow[t]{2}{*}{ Total $^{*} \mathrm{Q}_{\text {Breadth }}$} & & & & & & & $0.074^{+}$ & $0.075^{+}$ \\
\hline & & & & & & & [0.009] & [0.008] \\
\hline \multirow[t]{2}{*}{ Mkt. Cap. } & $0.323^{+}$ & $0.050^{* *}$ & $0.142^{* *}$ & $-0.477^{+}$ & $0.313^{+}$ & $0.071^{+}$ & $0.098^{*}$ & $-0.557^{+}$ \\
\hline & {$[0.040]$} & {$[0.021]$} & {$[0.057]$} & {$[0.060]$} & {$[0.039]$} & {$[0.020]$} & [0.057] & {$[0.056]$} \\
\hline \multirow[t]{2}{*}{$D_{P<5}$} & -0.039 & $-0.138^{+}$ & $-0.053^{* *}$ & $-0.292^{+}$ & $-0.054^{* *}$ & $-0.159^{+}$ & $-0.073^{+}$ & $-0.341^{+}$ \\
\hline & {$[0.025]$} & [0.034] & {$[0.025]$} & {$[0.040]$} & {$[0.025]$} & {$[0.033]$} & {$[0.025]$} & {$[0.035]$} \\
\hline \multirow[t]{2}{*}{ Tover } & $0.037^{+}$ & $0.017^{*}$ & $0.031^{+}$ & 0.005 & $0.035^{+}$ & 0.007 & $0.028^{+}$ & -0.007 \\
\hline & [0.009] & {$[0.008]$} & [0.009] & {$[0.008]$} & {$[0.009]$} & {$[0.008]$} & [0.009] & [0.008] \\
\hline \multirow[t]{2}{*}{$\mathrm{B} / \mathrm{M}$} & $0.038^{+}$ & $0.086^{+}$ & $0.035^{+}$ & $0.070^{+}$ & $0.039^{+}$ & $0.092^{+}$ & $0.035^{+}$ & $0.073^{+}$ \\
\hline & {$[0.011]$} & [0.018] & {$[0.011]$} & [0.016] & {$[0.011]$} & {$[0.018]$} & {$[0.011]$} & [0.016] \\
\hline \multirow[t]{2}{*}{ Momentum } & $-0.022^{+}$ & -0.01 & $-0.020^{+}$ & 0.003 & $-0.022^{+}$ & -0.014 & $-0.021^{+}$ & 0.002 \\
\hline & {$[0.004]$} & [0.009] & [0.004] & {$[0.010]$} & {$[0.004]$} & [0.008] & [0.004] & {$[0.010]$} \\
\hline \multirow[t]{2}{*}{ Constant } & -0.007 & $0.014^{+}$ & 0.001 & $0.024^{+}$ & $-0.046^{+}$ & $-0.046^{+}$ & $-0.050^{+}$ & $-0.027^{+}$ \\
\hline & {$[0.010]$} & {$[0.003]$} & {$[0.011]$} & {$[0.004]$} & {$[0.012]$} & {$[0.005]$} & {$[0.012]$} & {$[0.007]$} \\
\hline Obs. & 33,251 & 33,251 & 33,251 & 33,251 & 33,251 & 33,251 & 33,251 & 33,251 \\
\hline Firms & 3,385 & 3,385 & 3,385 & 3,385 & 3,385 & 3,385 & 3,385 & 3,385 \\
\hline$R^{2}$ & 0.50 & 0.60 & 0.50 & 0.60 & 0.52 & 0.61 & 0.51 & 0.61 \\
\hline
\end{tabular}




\section{Table IV \\ Equity Loan Characteristics \& Corporate Ownership Structure}

The table regress equity loan characteristics as a function of ownership and voting rights structure, with quarterly stock data from January 2005 to June 2008 of U.S. firms. Each column corresponds to a different estimator, showing results for fixed-effects and Fama-Macbeth regressions. In Panel A the dependent variable is Loan Fee defined as the quarterly average of daily loan fees weighted by loan size. Panel B displays results for the quarterly average of the daily standard deviation of equal-weighted loan fees. All variables are standardized each quarter such that they have zero mean and unit standard deviation. Total is total institutional ownership, $H H I$ is concentration of ownership measured by the Hirschman-Herfindahl index, Breadth is the number of institutional investors as in Chen, Hong, and Stein (2002). All regressions include year-quarter dummies and the following control variables: Mkt. Cap. denotes market capitalization, $D_{P<5}$ is a dummy variable equal to one if the quarterly average price is below five dollars, Turnover measures the quarterly average of daily stock turnover, $\mathrm{B} / \mathrm{M}$ the book-to-market ratio, and Momentum is the cumulative return in the previous two quarters. Fixed-effect regressions standard deviations are clustered at the firm level. We report standard deviations in brackets and significance levels are indicated as follows: $+=$ statistical significance at the $1 \%$ level, $* *=$ significant at the $5 \%$ percent level, $*=$ significant at the $10 \%$ level.

Panel A: Fee Average

Panel B: Fee Volatility

\begin{tabular}{lcccc|cccc}
\hline Variable & FE & F-M & FE & F-M & FE & F-M & FE & F-M \\
\hline Total & -0.007 & $-0.211^{+}$ & 0.015 & $-0.195^{+}$ & -0.016 & $-0.243^{+}$ & -0.005 & $-0.241^{+}$ \\
& {$[0.030]$} & {$[0.005]$} & {$[0.028]$} & {$[0.007]$} & {$[0.033]$} & {$[0.014]$} & {$[0.033]$} & {$[0.011]$} \\
HHI & $0.067^{+}$ & $0.171^{+}$ & & & $0.047^{*}$ & $0.126^{+}$ & & \\
& {$[0.021]$} & {$[0.012]$} & & & {$[0.027]$} & {$[0.018]$} & & \\
Breadth & & & $-0.200^{+}$ & $-0.340^{+}$ & & & $-0.119^{*}$ & $-0.211^{+}$ \\
& & & {$[0.063]$} & {$[0.032]$} & & & {$[0.069]$} & {$[0.059]$} \\
Mkt. Cap. & $-0.594^{+}$ & $-0.087^{+}$ & $-0.475^{+}$ & $0.166^{+}$ & $-0.643^{+}$ & $-0.111^{+}$ & $-0.583^{+}$ & 0.04 \\
& {$[0.069]$} & {$[0.012]$} & {$[0.090]$} & {$[0.023]$} & {$[0.083]$} & {$[0.017]$} & {$[0.102]$} & {$[0.038]$} \\
$D_{P<5}$ & -0.063 & $0.489^{+}$ & -0.044 & $0.597^{+}$ & $-0.119^{*}$ & $0.541^{+}$ & $-0.110^{*}$ & $0.606^{+}$ \\
& {$[0.050]$} & {$[0.042]$} & {$[0.051]$} & {$[0.045]$} & {$[0.061]$} & {$[0.053]$} & {$[0.061]$} & {$[0.058]$} \\
Tover & $0.122^{+}$ & $0.256^{+}$ & $0.124^{+}$ & $0.255^{+}$ & $0.098^{+}$ & $0.234^{+}$ & $0.099^{+}$ & $0.232^{+}$ \\
& {$[0.019]$} & {$[0.012]$} & {$[0.019]$} & {$[0.011]$} & {$[0.014]$} & {$[0.015]$} & {$[0.014]$} & {$[0.014]$} \\
B/M & -0.018 & $-0.096^{+}$ & -0.015 & $-0.088^{+}$ & -0.034 & $-0.085^{+}$ & -0.033 & $-0.079^{+}$ \\
& {$[0.017]$} & {$[0.006]$} & {$[0.017]$} & {$[0.005]$} & {$[0.021]$} & {$[0.005]$} & {$[0.021]$} & {$[0.004]$} \\
Momentum & 0.001 & $-0.042^{+}$ & -0.001 & $-0.050^{+}$ & $-0.018^{* *}$ & $-0.079^{+}$ & $-0.019^{* *}$ & $-0.083^{+}$ \\
& {$[0.008]$} & {$[0.013]$} & {$[0.008]$} & {$[0.013]$} & {$[0.007]$} & {$[0.010]$} & {$[0.007]$} & {$[0.010]$} \\
Constant & -0.024 & $-0.035^{+}$ & $-0.030^{* *}$ & $-0.043^{+}$ & $-0.027^{*}$ & $-0.044^{+}$ & $-0.031^{* *}$ & $-0.050^{+}$ \\
& {$[0.015]$} & {$[0.002]$} & {$[0.015]$} & {$[0.003]$} & {$[0.015]$} & {$[0.003]$} & {$[0.015]$} & {$[0.004]$} \\
\hline Obs. & 33,251 & 33,251 & 33,251 & 33,251 & 21,869 & 21,869 & 21,869 & 21,869 \\
Firms & 3,385 & 3,385 & 3,385 & 3,385 & 3,263 & 3,263 & 3,263 & 3,263 \\
$R^{2}$ & 0.08 & 0.20 & 0.07 & 0.19 & 0.08 & 0.22 & 0.08 & 0.21 \\
\hline
\end{tabular}




\section{Table V}

\section{Equity Loan Characteristics \& Corporate Ownership Structure: Specialness and Loan Type}

Using quarterly stock data from January 2005 to June 2008 of U.S. firms, in Panel A we use logistic regressions to explain the likelihood that a share is "on special" (i.e. has annualized loan fee above 100 basis points). In Panel B the dependent variable is the probability of fixed-term equity loans (defined as the quarterly average of the daily fraction of equity loans with fixed-term maturity). Each panel reports estimation coefficients and marginal effects, i.e., expected changes in probability given a one standard deviation increase in an explanatory variable. Total is total institutional ownership, $H H I$ is concentration of ownership measured by the Hirschman-Herfindahl index, Breadth is the number of institutional investors as in Chen, Hong, and Stein (2002). All regressions include year-quarter dummies and the following control variables: Mkt. Cap. denotes market capitalization, $D_{P<5}$ is a dummy variable equal to one if the quarterly average price is below five dollars, Turnover measures the quarterly average of daily stock turnover, B/M the book-to-market ratio, and Momentum is cumulative return in the previous two quarters. We report standard deviations clustered at the firm-level in brackets and significance levels are indicated as follows: $+=$ significant at the $1 \%$ level, $* *=$ significant at the $5 \%$ percent level, $*=$ significant at the $10 \%$ level.

\begin{tabular}{lcc|lcc}
\multicolumn{5}{c}{ Panel A: Probability of Stock being “On Special” } \\
\hline \multicolumn{3}{c}{ Coefficients } & & \multicolumn{3}{|c}{ Marginal Effect (Around Average) } \\
\hline Total & $-0.569^{+}$ & $-0.507^{+}$ & Total & $-0.034^{+}$ & $-0.030^{+}$ \\
& {$[0.061]$} & {$[0.071]$} & & {$[0.003]$} & {$[0.004]$} \\
HHI & $0.241^{+}$ & & HHI & $0.014^{+}$ & \\
& {$[0.038]$} & & & {$[0.002]$} & \\
\multirow{2}{*}{ Breadth } & & $-0.642^{+}$ & Breadth & & $-0.038^{+}$ \\
& & {$[0.140]$} & & & {$[0.008]$} \\
\hline Obs. & 33,251 & 33,251 & Obs. & 33,251 & 33,251 \\
Firms & 3,385 & 3,385 & Firms & 3,385 & 3,385 \\
Pseudo- $R^{2}$ & 0.27 & 0.27 & $R^{2}$ & 0.27 & 0.27 \\
\hline
\end{tabular}

Panel B: Probability of a Fixed-Term Loan

\begin{tabular}{lcc|lcc}
\hline \multicolumn{3}{c|}{ Coefficients } & \multicolumn{3}{|c}{ Marginal Effect (Around Average) } \\
\hline Total & $0.586^{+}$ & $0.466^{+}$ & Total & $0.064^{+}$ & $0.051^{+}$ \\
& {$[0.038]$} & {$[0.043]$} & & {$[0.004]$} & {$[0.005]$} \\
HHI & $-0.254^{+}$ & & HHI & $-0.028^{+}$ & \\
& {$[0.043]$} & & & {$[0.005]$} & \\
Breadth & & $1.077^{+}$ & Breadth & & $0.117^{+}$ \\
& & {$[0.153]$} & & & {$[0.016]$} \\
\hline Obs. & 33,251 & 33,251 & & & \\
Firms & 3,385 & 3,385 & & & \\
Pseudo- $R^{2}$ & 0.50 & 0.50 & & & \\
\hline
\end{tabular}




\section{Table VI}

\section{Arbitrage Risk \& Corporate Ownership Structure}

The table reports results of Fama-Macbeth regressions of arbitrage risk as a function of ownership structure, with quarterly U.S. stock data from January 2005 to June 2008. Arbitrage risk measured as the idiosyncratic risk of daily returns based on the Carhart (1997) 4-factor model within a quarter. All variables are standardized each quarter such that they have zero mean and unit standard deviation. Total is total institutional ownership, $H H I$ is concentration of ownership measured by the Hirschman-Herfindahl index, Breadth is the number of institutional investors as in Chen, Hong, and Stein (2002), Mkt. Cap. denotes market capitalization, $D_{P<5}$ is a dummy variable equal to one if the quarterly average price is below five dollars, Turnover measures the quarterly average of daily stock turnover, B/M the book-to-market ratio, and Momentum is the cumulative return in the previous two quarters. All regressions include year-quarter dummies, with standard deviations clustered at the firm level. We report standard deviations in brackets and significance levels are indicated as follows: $+=$ statistical significance at the $1 \%$ level, ${ }^{* *}=$ significant at the $5 \%$ percent level, ${ }^{*}=$ significant at the $10 \%$ level.

\section{Arbitrage Risk}

\begin{tabular}{lcccc}
\hline Supply & $0.030^{+}$ & $-0.061^{+}$ & $0.027^{+}$ & $-0.075^{+}$ \\
& {$[0.010]$} & {$[0.012]$} & {$[0.010]$} & {$[0.013]$} \\
Fee(VW) & 0.012 & $0.078^{+}$ & 0.014 & $0.084^{+}$ \\
& {$[0.012]$} & {$[0.004]$} & {$[0.012]$} & {$[0.004]$} \\
Total & $-0.248^{+}$ & $-0.045^{+}$ & $-0.276^{+}$ & $-0.049^{+}$ \\
& {$[0.024]$} & {$[0.011]$} & {$[0.022]$} & {$[0.011]$} \\
HHI & 0.014 & $0.052^{+}$ & & \\
& {$[0.017]$} & {$[0.007]$} & & \\
Breadth & & & $0.153^{+}$ & -0.004 \\
& & & {$[0.046]$} & {$[0.018]$} \\
Mkt. Cap. & $-0.649^{+}$ & $-0.393^{+}$ & $-0.770^{+}$ & $-0.402^{+}$ \\
& {$[0.040]$} & {$[0.011]$} & {$[0.056]$} & {$[0.025]$} \\
$D_{P<5}$ & $0.287^{+}$ & $0.813^{+}$ & $0.284^{+}$ & $0.826^{+}$ \\
& {$[0.045]$} & {$[0.033]$} & {$[0.045]$} & {$[0.033]$} \\
Tover & $0.536^{+}$ & $0.435^{+}$ & $0.532^{+}$ & $0.429^{+}$ \\
& {$[0.037]$} & {$[0.012]$} & {$[0.037]$} & {$[0.012]$} \\
B/M & -0.003 & $-0.073^{+}$ & -0.005 & $-0.071^{+}$ \\
& {$[0.015]$} & {$[0.012]$} & {$[0.015]$} & {$[0.012]$} \\
Momentum & -0.002 & -0.005 & -0.001 & -0.005 \\
& {$[0.007]$} & {$[0.016]$} & {$[0.007]$} & {$[0.016]$} \\
Constant & $-0.031^{* *}$ & $-0.062^{+}$ & $-0.026^{*}$ & $-0.063^{+}$ \\
& {$[0.013]$} & {$[0.003]$} & {$[0.013]$} & {$[0.003]$} \\
\hline Obs. & 33,251 & 33,251 & 33,251 & 33,251 \\
Firms & 3,385 & 3,385 & 3,385 & 3,385 \\
$R^{2}$ & 0.280 & 0.510 & 0.280 & 0.510 \\
\hline
\end{tabular}




\section{Table VII \\ Lending Shocks \& Institutional Ownership Structure: First Month-of-Quarter}

The table uses logistic regressions to explain lending supply and demand shocks as a function of lagged stock characteristics, and tests for reverse causality with total institutional ownership and concentration of ownership. Price data is from CRSP and stock ownership data from SEC's 13F fillings between January 2005 to June 2008. "All Months" use all available monthly observations, while "First Month" only used the first monthly observation in a given quarter. In Panel A we present results for demand shocks: DOUT is a dummy variable equal to 1 if there is an increase in loan fees and loaned amount relative to the previous month and DIN is a dummy variable equal to 1 if there is a decrease in loan fees and loaned amount relative to the previous month. All variables are standardized each month such that they have zero mean and unit standard deviation. Supply is the lending supply, Total is the quarterly total institutional ownership, $\mathrm{HHI}$ is the concentration of ownership measured by the Hirschman-Herfindahl index, Breadth is the number of institutional holders of the stock, Mkt. Cap. denotes market capitalization, Turnover is average daily stock turnover, $\mathrm{B} / \mathrm{M}$ is the book-to-market ratio, Mom1 is the stock return in the previous month, and Mom12M is the cumulative stock return in the previous 12 months. All regressions include year-quarter dummies. Panel A reports logit regression coefficients and marginal effects, i.e., expected changes in probability given a one standard deviation increase in an explanatory variable around its mean. In Panel B we display OLS coefficients using Total and HHI as dependent variables. We report standard deviations in brackets and significance levels are indicated as follows: $+=$ significant at the $1 \%$ level, $* *=$ significant at the $5 \%$ percent level, $*=$ significant at the $10 \%$ level.

\begin{tabular}{|c|c|c|c|c|c|}
\hline \multicolumn{3}{|c|}{ Coefficients } & \multicolumn{3}{|c|}{ Marginal Effect (Around Average) } \\
\hline & DOUT & $\overline{\mathrm{DIN}}$ & & DOUT & DIN \\
\hline Supply $_{t-1}$ & $\begin{array}{c}-0.144^{+} \\
{[0.025]}\end{array}$ & $\begin{array}{l}0.075^{+} \\
{[0.023]}\end{array}$ & Supply $_{t-1}$ & $\begin{array}{l}-0.023^{+} \\
{[0.004]}\end{array}$ & $\begin{array}{l}0.015^{+} \\
{[0.0041}\end{array}$ \\
\hline Total $_{t-1}$ & $\begin{array}{l}0.182^{+} \\
{[0.026]}\end{array}$ & $\begin{array}{l}-0.156^{+} \\
{[0.025]}\end{array}$ & Total $_{t-1}$ & $\begin{array}{l}0.029^{+} \\
{[0.004]}\end{array}$ & $\begin{array}{c}-0.031^{+} \\
{[0.005]}\end{array}$ \\
\hline $\mathrm{HHI}_{t-1}$ & $\begin{array}{l}-0.072^{+} \\
{[0.022]}\end{array}$ & $\begin{array}{c}0.03 \\
{[0.021]}\end{array}$ & $\mathrm{HHI}_{t-1}$ & $\begin{array}{l}-0.012^{+} \\
{[0.004]}\end{array}$ & $\begin{array}{c}0.006 \\
{[0.004]}\end{array}$ \\
\hline Mkt. Cap ${ }_{t-1}$ & $\begin{array}{c}-0.156^{+} \\
{[0.026]}\end{array}$ & $\begin{array}{l}0.237^{+} \\
{[0.027]}\end{array}$ & Breadth $_{t-1}$ & $\begin{array}{l}-0.025^{+} \\
{[0.004]}\end{array}$ & $\begin{array}{l}0.047^{+} \\
{[0.005]}\end{array}$ \\
\hline Tover $_{t-1}$ & $\begin{array}{c}-0.077^{+} \\
{[0.015]}\end{array}$ & $\begin{array}{l}0.039^{+} \\
{[0.014]}\end{array}$ & Mkt. $\mathrm{Cap}_{t-1}$ & $\begin{array}{l}-0.012^{+} \\
{[0.002]}\end{array}$ & $\begin{array}{l}0.008^{+} \\
{[0.003]}\end{array}$ \\
\hline $\mathrm{B} / \mathrm{M}_{t-1}$ & $\begin{array}{c}-0.021 \\
{[0.016]}\end{array}$ & $\begin{array}{l}0.028^{*} \\
{[0.016]}\end{array}$ & Tover $_{t-1}$ & $\begin{array}{l}-0.003 \\
{[0.003]}\end{array}$ & $\begin{array}{l}0.006^{*} \\
{[0.003]}\end{array}$ \\
\hline 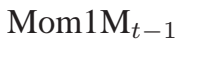 & $\begin{array}{l}0.226^{+} \\
{[0.018]}\end{array}$ & $\begin{array}{c}-0.197^{+} \\
{[0.021]}\end{array}$ & $\operatorname{Mom}_{1} \mathrm{M}_{t-1}$ & $\begin{array}{l}0.036^{+} \\
{[0.003]}\end{array}$ & $\begin{array}{c}-0.039^{+} \\
{[0.004]}\end{array}$ \\
\hline Mom $12 \mathrm{M}_{t-1}$ & $\begin{array}{c}-0.069^{+} \\
{[0.020]}\end{array}$ & $\begin{array}{l}0.042^{* *} \\
{[0.019]}\end{array}$ & Mom12 $\mathbf{M}_{t-1}$ & $\begin{array}{l}-0.011^{+} \\
{[0.003]}\end{array}$ & $\begin{array}{l}0.008^{* *} \\
{[0.004]}\end{array}$ \\
\hline Constant & $\begin{array}{c}-1.161^{+} \\
{[0.057]}\end{array}$ & $\begin{array}{c}-1.382^{+} \\
{[0.059]}\end{array}$ & & & \\
\hline $\begin{array}{l}\text { Obs. } \\
\text { Firms } \\
R^{2}\end{array}$ & $\begin{array}{c}28,993 \\
3,316 \\
0.06\end{array}$ & $\begin{array}{c}28,993 \\
3,316 \\
0.06\end{array}$ & & & \\
\hline
\end{tabular}


Table VIII

\section{Stock Returns, Equity Lending Shocks \& Ownership Structure-Using first month of the quarter with lagged variables}

The table regress contemporaneous abnormal returns as a function of equity lending market shocks and corporate ownership structure, using monthly stock data from January 2005 to June 2008 of U.S firms. Abnormal returns are computed as the difference in monthly returns between the stock and a characteristics-matched benchmark portfolio sorted on market capitalization, book-to-market and momentum as in Daniel, Grinblatt, Titman, and Wermers (1997). DSHIFT captures contemporaneous demand shocks, being equal to 1 if there is an increase in lending fees and loan quantity relative to the previous month, -1 if there is a decrease in both variables, and 0 otherwise. Total is total institutional ownership, HHI is concentration of ownership measured by the Hirschman-Herfindahl index, Turnover is average monthly stock turnover. $\mathrm{Q}_{z}$ represent the quintile sorted according to variable $z$. Regressions only include abnormal returns on the first month of a quarter and include calendar-month dummies. Robust standard deviations are clustered at the firm level and shown between brackets. Significance levels are indicated as follows: $+=$ statistical significance at the $1 \%$ level, $*=$ significant at the $5 \%$ percent level, $* *=$ significant at the $10 \%$ level.

\begin{tabular}{|c|c|c|c|}
\hline \multirow{3}{*}{ DSHIFT } & \multicolumn{3}{|c|}{ First month of quarter } \\
\hline & $-1.780^{+}$ & $-1.252^{+}$ & $-0.573^{* *}$ \\
\hline & [0.085] & {$[0.175]$} & [0.301] \\
\hline DSHIFT*Lag[Q ${ }{ } w n]$ & & & $-0.161^{* *}$ \\
\hline DSHIFT*Lag $\left[\mathrm{Q}_{H H I}\right]$ & & $-0.187^{+}$ & $-0.253^{+}$ \\
\hline $\mathrm{Lag}[\mathrm{O}$ & & $\begin{array}{c}{[0.058]} \\
0.048\end{array}$ & $\begin{array}{c}{[0.061]} \\
0.052\end{array}$ \\
\hline & & {$[0.045]$} & {$[0.044]$} \\
\hline $\operatorname{Lag}\left[\mathrm{Q}_{H H I}\right]$ & & $\begin{array}{l}-0.058 \\
-0.0481\end{array}$ & -0.042 \\
\hline Lag[Turnover] & $0.016^{+}$ & $0.018^{+}$ & $0.018^{+}$ \\
\hline $\mathrm{L} a \mathrm{a}[\Delta$ Turnover $]$ & $\begin{array}{l}{[0.004]} \\
0.084^{+}\end{array}$ & $\begin{array}{l}{[0.005]} \\
0.080^{+}\end{array}$ & $\begin{array}{l}{[0.005]} \\
0.080^{+}\end{array}$ \\
\hline & {$[0.031]$} & {$[0.031]$} & {$[0.031]$} \\
\hline Constant & $\begin{array}{c}-0.565^{* *} \\
{[0.230]}\end{array}$ & $\begin{array}{l}-0.483 \\
{[0.326]}\end{array}$ & $\begin{array}{r}-0.539^{* *} \\
{[0.324]}\end{array}$ \\
\hline Obs. & 29,261 & 29,006 & 29,006 \\
\hline Firms & 3,299 & 3,283 & 3,283 \\
\hline
\end{tabular}




\section{Robustness Test: Top1 Institutional Ownership}

This table uses Top1 ownership as an alternative concentration to measure to explain lending supply, loan fee, loan fee volatility, arbitrage risk, the probability of a stock being special, and the probability of a loan being fixed-term as dependent variables. Total is the quarterly total institutional ownership, Mkt. Cap. denotes market capitalization, Top1 is the percentage held by the largest shareholder, Turnover is average daily stock turnover, B/M is the bookto-market ratio, Mom1 is the stock return in the previous month, and Mom12M is the cumulative stock return in the previous 12 months. All regressions include year-quarter dummies. We report standard deviations in brackets and significance levels are indicated as follows: $+=$ statistical significance at the $1 \%$ level, $* *=$ significant at the $5 \%$ percent level, *=significant at the $10 \%$ level.

Panel A: Fama-Macbeth Regressions

\begin{tabular}{lcccc|cccc}
\hline & Supply & Fee & Fee Vol & Arb. Risk & \multicolumn{3}{c}{ Specialness } & \multicolumn{2}{c}{ Loan Term } \\
\hline & F-M & F-M & F-M & F-M & Coeff. & Marg. Eff. & Coeff. & Marg. Eff. \\
\hline Total & $0.770^{+}$ & $-0.297^{+}$ & $-0.330^{+}$ & $-0.085^{+}$ & $-0.841^{+}$ & $-0.050^{+}$ & $0.688^{+}$ & $0.075^{+}$ \\
& {$[0.033]$} & {$[0.006]$} & {$[0.017]$} & {$[0.011]$} & {$[0.065]$} & {$[0.004]$} & {$[0.039]$} & {$[0.004]$} \\
Top1 & $-0.206^{+}$ & $0.072^{+}$ & $0.101^{+}$ & $0.047^{+}$ & $0.306^{+}$ & $0.019^{+}$ & $-0.152^{+}$ & $-0.015^{+}$ \\
& {$[0.015]$} & {$[0.008]$} & {$[0.008]$} & {$[0.003]$} & {$[0.032]$} & {$[0.002]$} & {$[0.025]$} & {$[0.003]$} \\
Mkt. Cap. & $0.066^{+}$ & $-0.122^{+}$ & $-0.127^{+}$ & $-0.399^{+}$ & $-1.023^{+}$ & $-0.061^{+}$ & $2.615^{+}$ & $0.285^{+}$ \\
& {$[0.020]$} & {$[0.014]$} & {$[0.020]$} & {$[0.011]$} & {$[0.080]$} & {$[0.005]$} & {$[0.055]$} & {$[0.003]$} \\
$D_{P<5}$ & $-0.168^{+}$ & $0.539^{+}$ & $0.566^{+}$ & $0.823^{+}$ & $0.602^{+}$ & $0.042^{+}$ & -0.058 & -0.006 \\
& {$[0.034]$} & {$[0.046]$} & {$[0.056]$} & {$[0.033]$} & {$[0.100]$} & {$[0.008]$} & {$[0.186]$} & {$[0.020]$} \\
Tover & 0.013 & $0.248^{+}$ & $0.234^{+}$ & $0.434^{+}$ & $0.743^{+}$ & $0.044^{+}$ & $0.189^{+}$ & $0.021^{+}$ \\
& {$[0.009]$} & {$[0.013]$} & {$[0.014]$} & {$[0.012]$} & {$[0.040]$} & {$[0.003]$} & {$[0.032]$} & {$[0.004]$} \\
B/M & $0.088^{+}$ & $-0.096^{+}$ & $-0.086^{+}$ & $-0.073^{+}$ & $-0.388^{+}$ & $-0.023^{+}$ & $0.187^{+}$ & $0.020^{+}$ \\
& {$[0.017]$} & {$[0.006]$} & {$[0.005]$} & {$[0.011]$} & {$[0.054]$} & {$[0.003]$} & {$[0.032]$} & {$[0.004]$} \\
Momentum & -0.014 & $-0.042^{+}$ & $-0.076^{+}$ & -0.004 & $-0.148^{+}$ & $-0.009^{+}$ & $-0.226^{+}$ & $-0.025^{+}$ \\
& {$[0.008]$} & {$[0.014]$} & {$[0.010]$} & {$[0.016]$} & {$[0.026]$} & {$[0.002]$} & {$[0.023]$} & {$[0.003]$} \\
Supply & & & & $-0.055^{+}$ & & & & \\
& & & & {$[0.011]$} & & & & \\
Fee(VW) & & & & $0.082^{+}$ & & & & \\
& & & & {$[0.004]$} & & & & \\
Constant & $0.016^{+}$ & $-0.039^{+}$ & $-0.047^{+}$ & $-0.062^{+}$ & $-3.284^{+}$ & & $-0.419^{+}$ & \\
& {$[0.003]$} & {$[0.003]$} & {$[0.004]$} & {$[0.003]$} & {$[0.104]$} & & {$[0.061]$} & \\
\hline Obs. & 33,251 & 33,251 & 21,869 & 33,251 & 33,251 & 33,251 & 33251 & 33251 \\
Firms & 3,385 & 3,385 & 3,385 & 3,385 & 3,385 & 3,385 & 3263 & 3385 \\
$R^{2}$ & 0.610 & 0.190 & 0.210 & 0.510 & 0.280 & 0.280 & 0.49 & 0.49 \\
\hline
\end{tabular}




\section{Table X}

\section{Robustness Test: HS1 Measure}

This table uses institutional investor's measure of influence (HS1) as an alternative concentration to measure to explain lending supply, loan fee, loan fee volatility, arbitrage risk, the probability of a stock being special, and the probability of a loan being fixed-term as dependent variables. Total is the quarterly total institutional ownership, Mkt. Cap. denotes market capitalization, HS1 measures investors' influence as in Hartzell and Starks (2003), Turnover is average daily stock turnover, $\mathrm{B} / \mathrm{M}$ is the book-to-market ratio, Mom1 is the stock return in the previous month, and Mom12M is the cumulative stock return in the previous 12 months. All regressions include year-quarter dummies. We report standard deviations in brackets and significance levels are indicated as follows: $+=$ statistical significance at the $1 \%$ level, $* *=$ significant at the $5 \%$ percent level, $*=$ significant at the $10 \%$ level.

Panel A: Fama-Macbeth Regressions

Panel B: Logit Regressions

\begin{tabular}{lcccc|cccc}
\hline & Supply & Fee & Fee Vol & Arb. Risk & \multicolumn{3}{c}{ Specialness } & \multicolumn{2}{c}{ Loan Term } \\
\hline & F-M & F-M & F-M & F-M & Coeff. & Marg. Eff. & Coeff. & Marg. Eff. \\
\hline Total & $0.770^{+}$ & $-0.297^{+}$ & $-0.330^{+}$ & $-0.085^{+}$ & $-0.841^{+}$ & $-0.050^{+}$ & $0.688^{+}$ & $0.075^{+}$ \\
& {$[0.033]$} & {$[0.006]$} & {$[0.017]$} & {$[0.011]$} & {$[0.065]$} & {$[0.004]$} & {$[0.039]$} & {$[0.004]$} \\
HS1 & $-0.206^{+}$ & $0.072^{+}$ & $0.101^{+}$ & $0.047^{+}$ & $0.306^{+}$ & $0.019^{+}$ & $-0.152^{+}$ & $-0.015^{+}$ \\
& {$[0.015]$} & {$[0.008]$} & {$[0.008]$} & {$[0.003]$} & {$[0.032]$} & {$[0.002]$} & {$[0.025]$} & {$[0.003]$} \\
Mkt. Cap. & $0.066^{+}$ & $-0.122^{+}$ & $-0.127^{+}$ & $-0.399^{+}$ & $-1.023^{+}$ & $-0.061^{+}$ & $2.615^{+}$ & $0.285^{+}$ \\
& {$[0.020]$} & {$[0.014]$} & {$[0.020]$} & {$[0.011]$} & {$[0.080]$} & {$[0.005]$} & {$[0.055]$} & {$[0.003]$} \\
$D_{P<5}$ & $-0.168^{+}$ & $0.539^{+}$ & $0.566^{+}$ & $0.823^{+}$ & $0.602^{+}$ & $0.042^{+}$ & -0.058 & -0.006 \\
& {$[0.034]$} & {$[0.046]$} & {$[0.056]$} & {$[0.033]$} & {$[0.100]$} & {$[0.008]$} & {$[0.186]$} & {$[0.020]$} \\
Tover & 0.013 & $0.248^{+}$ & $0.234^{+}$ & $0.434^{+}$ & $0.743^{+}$ & $0.044^{+}$ & $0.189^{+}$ & $0.021^{+}$ \\
& {$[0.009]$} & {$[0.013]$} & {$[0.014]$} & {$[0.012]$} & {$[0.040]$} & {$[0.003]$} & {$[0.032]$} & {$[0.004]$} \\
B/M & $0.088^{+}$ & $-0.096^{+}$ & $-0.086^{+}$ & $-0.073^{+}$ & $-0.388^{+}$ & $-0.023^{+}$ & $0.187^{+}$ & $0.020^{+}$ \\
& {$[0.017]$} & {$[0.006]$} & {$[0.005]$} & {$[0.011]$} & {$[0.054]$} & {$[0.003]$} & {$[0.032]$} & {$[0.004]$} \\
Momentum & -0.014 & $-0.042^{+}$ & $-0.076^{+}$ & -0.004 & $-0.148^{+}$ & $-0.009^{+}$ & $-0.226^{+}$ & $-0.025^{+}$ \\
& {$[0.008]$} & {$[0.014]$} & {$[0.010]$} & {$[0.016]$} & {$[0.026]$} & {$[0.002]$} & {$[0.023]$} & {$[0.003]$} \\
Supply & & & & $-0.055^{+}$ & & & & \\
\multirow{4}{*}{ Fee(VW) } & & & & {$[0.011]$} & & & & \\
\multirow{2}{*}{ Constant } & $0.0166^{+}$ & $-0.039^{+}$ & $-0.047^{+}$ & $-0.062^{+}$ & $-3.284^{+}$ & & $-0.419^{+}$ & \\
& {$[0.003]$} & {$[0.003]$} & {$[0.004]$} & {$[0.003]$} & {$[0.104]$} & & {$[0.061]$} & \\
Obs. & 33,251 & 33,251 & 21,869 & 33,251 & 33,251 & 33,251 & 33,251 & 33,251 \\
Firms & 3,385 & 3,385 & 3,385 & 3,385 & 3,385 & 3,385 & 3,385 & 3,385 \\
$R^{2}$ & 0.610 & 0.190 & 0.210 & 0.510 & 0.280 & 0.280 & 0.490 & 0.490 \\
\hline
\end{tabular}




\section{Table XI}

\section{Robustness Test: Dynamic Panel Model (DPM) Regressions}

This table reports results using Blundell and Bond (1998)'s dynamic panel regressions. All variables are standardized each month such that they have zero mean and unit standard deviation. Supply is the lending supply, Total is the quarterly total institutional ownership, $H H I$ is the concentration of ownership measured by the Hirschman-Herfindahl index, Breadth is the number of institutional holders of the stock, Mkt. Cap. denotes market capitalization, Turnover is average daily stock turnover, $\mathrm{B} / \mathrm{M}$ is the book-to-market ratio, Mom1 is the stock return in the previous month, and Mom12M is the cumulative stock return in the previous 12 months. All regressions include year-quarter dummies. We report standard deviations in brackets and significance levels are indicated as follows: +=statistical significance at the $1 \%$ level, **=significant at the $5 \%$ percent level, *=significant at the $10 \%$ level.

\begin{tabular}{l|cc|cc|cc}
\multicolumn{7}{c}{ DPM Regressions } \\
\hline & \multicolumn{2}{|c}{ Supply } & \multicolumn{2}{|c}{ Fee } & \multicolumn{2}{c}{ Fee Vol } \\
\hline Dep. Var. ${ }_{t-1}$ & $0.886^{+}$ & $0.879^{+}$ & $1.228^{+}$ & $0.585^{+}$ & $0.748^{+}$ & $0.727^{+}$ \\
& {$[0.173]$} & {$[0.170]$} & {$[0.186]$} & {$[0.171]$} & {$[0.037]$} & {$[0.077]$} \\
Dep. Var. $t-2$ & $-0.260^{*}$ & $-0.269^{*}$ & $-0.354^{* *}$ & $0.266^{*}$ & & \\
& {$[0.146]$} & {$[0.142]$} & {$[0.173]$} & {$[0.156]$} & & \\
Total & $0.219^{+}$ & $0.141^{+}$ & $-0.065^{+}$ & $-0.089^{+}$ & $-0.099^{+}$ & $-0.257^{+}$ \\
& {$[0.023]$} & {$[0.017]$} & {$[0.015]$} & {$[0.015]$} & {$[0.033]$} & {$[0.088]$} \\
HHI & $-0.123^{+}$ & & $0.068^{+}$ & & $0.088^{* *}$ & \\
& {$[0.015]$} & & {$[0.019]$} & & {$[0.040]$} & \\
Breadth & & $0.685^{+}$ & & $-0.177^{+}$ & & $-0.158^{*}$ \\
& & {$[0.083]$} & & {$[0.046]$} & & {$[0.084]$} \\
Mkt. Cap. & $0.143^{+}$ & $-0.429^{+}$ & $-0.127^{+}$ & -0.022 & -0.1 & $-0.284^{* *}$ \\
& {$[0.030]$} & {$[0.057]$} & {$[0.024]$} & {$[0.024]$} & {$[0.076]$} & {$[0.117]$} \\
$D$ & $-0.305^{+}$ & $-0.396^{+}$ & $-0.293^{* *}$ & $-0.392^{+}$ & -0.241 & $-1.521^{*}$ \\
& {$[0.084]$} & {$[0.089]$} & {$[0.114]$} & {$[0.120]$} & {$[0.426]$} & {$[0.847]$} \\
Tover & $0.061^{+}$ & $0.045^{+}$ & $0.032^{+}$ & $0.061^{+}$ & $0.088^{+}$ & $0.064^{+}$ \\
& {$[0.013]$} & {$[0.012]$} & {$[0.011]$} & {$[0.009]$} & {$[0.010]$} & {$[0.017]$} \\
B/M & $0.331^{+}$ & $0.290^{+}$ & -0.008 & 0.001 & $-0.024^{+}$ & $-0.034^{* *}$ \\
& {$[0.117]$} & {$[0.112]$} & {$[0.007]$} & {$[0.005]$} & {$[0.007]$} & {$[0.016]$} \\
Momentum & $-0.361^{+}$ & $-0.337^{+}$ & $-0.016^{* *}$ & $-0.029^{+}$ & $-0.054^{+}$ & $-0.035^{+}$ \\
& {$[0.123]$} & {$[0.119]$} & {$[0.007]$} & {$[0.005]$} & {$[0.014]$} & {$[0.013]$} \\
\hline Obs. & 22,235 & 22,235 & 22,235 & 22,235 & 16,990 & 16,990 \\
Firms & 2,979 & 2,979 & 2,979 & 2,979 & 3,045 & 3,045 \\
Sargan-p & 0.09 & 0.19 & 0.27 & 0.07 & 0.40 & 0.63 \\
\hline
\end{tabular}


Table XII

\section{Lending Shocks \& Institutional Ownership Structure: Causality}

The table uses logistic regressions to examine for reverse causality in the results presented in Panel B of Table VII. Price data is from CRSP and stock ownership data from SEC's 13F fillings between January 2005 to June 2008. DOUT is a dummy variable equal to 1 if there is an increase in loan fees and loaned amount relative to the previous month and $D I N$ is a dummy variable equal to 1 if there is a decrease in loan fees and loaned amount relative to the previous month. All variables are standardized each month such that they have zero mean and unit standard deviation. Supply is the lending supply, Total is the quarterly total institutional ownership, $\mathrm{HHI}$ is the concentration of ownership measured by the Hirschman-Herfindahl index, Mkt. Cap. denotes market capitalization, Turnover is average daily stock turnover, $\mathrm{B} / \mathrm{M}$ is the book-to-market ratio, Mom1 is the stock return in the previous month, and Mom12M is the cumulative stock return in the previous 12 months. All regressions include year-quarter dummies. We report standard deviations in brackets and significance levels are indicated as follows: $+=$ significant at the $1 \%$ level, $* *=$ significant at the $5 \%$ percent level, $*=$ significant at the $10 \%$ level.

\begin{tabular}{|c|c|c|}
\hline & Total & HHI \\
\hline \multirow{2}{*}{$\operatorname{DOUT}_{t-1}$} & -0.011 & -0.006 \\
\hline & [0.014] & [0.021] \\
\hline \multirow{2}{*}{$\operatorname{DIN}_{t-1}$} & -0.008 & $-0.037^{+}$ \\
\hline & [0.013] & [0.011] \\
\hline \multirow{2}{*}{ Supply $_{t-1}$} & $0.616^{+}$ & $-0.334^{+}$ \\
\hline & [0.027] & [0.024] \\
\hline \multirow[t]{2}{*}{ Mkt. Cap ${ }_{t-1}$} & $0.093^{+}$ & $-0.260^{+}$ \\
\hline & [0.011] & {$[0.006]$} \\
\hline \multirow[t]{2}{*}{$\operatorname{Mom}_{1} \mathrm{M}_{t-1}$} & $0.027^{* *}$ & $-0.030^{+}$ \\
\hline & [0.010] & [0.007] \\
\hline \multirow[t]{2}{*}{$\operatorname{Mom} 12 \mathrm{M}_{t-1}$} & -0.006 & $-0.047^{+}$ \\
\hline & [0.010] & [0.005] \\
\hline \multirow[t]{2}{*}{ Tover $_{t-1}$} & $0.173^{+}$ & $-0.092^{+}$ \\
\hline & [0.009] & [0.006] \\
\hline \multirow[t]{2}{*}{$\mathrm{B} / \mathrm{M}_{t-1}$} & $-0.043^{* *}$ & $0.038^{+}$ \\
\hline & [0.018] & [0.011] \\
\hline \multirow{2}{*}{ Constant } & 0.024 & -0.017 \\
\hline & [0.018] & [0.017] \\
\hline Obs. & 28,993 & 28,993 \\
\hline Firms & 3,283 & 3,283 \\
\hline$R^{2}$ & 0.54 & 0.32 \\
\hline
\end{tabular}

